The Role of Taxes in the Disconnect between Corporate Performance and Economic Growth

Urooj Khan

Suresh Nallareddy

Ethan Rouen

Working Paper 18-006 


\title{
The Role of Taxes in the Disconnect between Corporate Performance and Economic Growth
}

\author{
Urooj Khan
}

Columbia University

Suresh Nallareddy

Duke University

Ethan Rouen

Harvard Business School

Working Paper 18-006 


\title{
The Role of Taxes in the Disconnect between Corporate Performance and Economic Growth ${ }^{*}$
}

\author{
Urooj Khan \\ Columbia University \\ uk2117@gsb.columbia.edu
}

\author{
Suresh Nallareddy \\ Duke University \\ suresh.nallareddy@duke.edu
}

\author{
Ethan Rouen \\ Harvard Business School \\ erouen@hbs.edu
}

June 2017

\begin{abstract}
*We are thankful to Dan Amiram, Sanjeev Bhojraj (discussant), John Donaldson, Scott Dyreng, Alex Edwards, Fabrizio Ferri, Paul Fischer, John Graham, Michelle Hanlon, Trevor Harris, Anne Heinrichs, Moritz Hiemann, Shane Heitzman, Alon Kalay, Amit Khandelwal, Wayne Landsman, Shelley Li (discussant), Hai Lu, Partha Mohanram (discussant), Emi Nakamura, Doron Nissim, Maria Ogneva, Stephen Penman, Shiva Rajgopal, Terry Shevlin, Lakshmanan Shivakumar, Jake Thornock, Mohan Venkatachalam, Ryan Wilson, Franco Wong, Pierre Yared, and participants of research seminars at Columbia Business School, Duke University, University of Toronto, Accounting Research Conference at Indian School of Business, Burton Conference at Columbia University, Conference on Financial Economics and Accounting, and the London Transatlantic Doctoral Conference for thoughtful discussions and feedback. We also thank economists at the Bureau of Economic Analysis for their assistance with data collection. All remaining errors are our own. We are grateful for financial support from the Center on Japanese Economy and Business at Columbia Business School.
\end{abstract}




\title{
The Role of Taxes in the Disconnect between Corporate Performance and Economic Growth
}

\begin{abstract}
We investigate the relation between the growth in corporate profits and the overall U.S. economy, focusing on the impact of the U.S. corporate tax regime on this relation. We document that the growth of corporate profits, on average, has outpaced the growth of the economy and this disconnect increases as the difference between the corporate income tax rate of the U.S. and the other OECD countries increases. The underlying mechanism is fewer corporate profits being channeled into subsequent domestic investments when the U.S. tax rate is relatively higher, leading to lower economic growth. Our findings have implications for policy setters.
\end{abstract}




\section{Introduction}

Without frictions, growth in corporate profits should be closely related to growth in the economy. ${ }^{1}$ However, in the presence of frictions, such as different corporate tax rates across jurisdictions, this relation may be altered or eliminated altogether. For example, during 2013, U.S. corporations earned $\$ 2.1$ trillion dollars in pre-tax profits - the highest level in at least 85 years — resulting in a $6 \%$ increase from the previous year (Norris 2014). In contrast, the U.S. economy grew by only $2 \%$ in the same period. In fact, for nearly a quarter century, corporate profits in the United States have grown at a faster rate than Gross Domestic Product (GDP).

In this paper, we investigate the relation between the performance of corporations and the overall economy with a focus on the impact of the U.S. corporate tax regime on this relation. Using a shock to the tax system, and cross-country, time-series, and cross-sectional analyses, we document that the relatively higher U.S. corporate tax rate — in relation to the average rate of the other countries in the OECD - combined with the tax treatment of foreign earnings of U.S. corporations have contributed to corporate profit growth not translating into subsequent overall economic growth. As a result, on average, the growth of corporate profits has outpaced the growth of the overall economy. While this disconnect between corporate profit growth and economic growth has received occasional coverage in the popular press (e.g., The Economist 2014), we provide a systematic and thorough examination of the issue and show the impact of the U.S. tax regime on the relation between the performance of U.S. corporations and overall economic growth in the United States.

\footnotetext{
${ }^{1}$ Corporate profits represent the portion of total income earned from current production that is accounted for by U.S. corporations, public and private. In our analyses, we use domestic and national corporate profits estimates prepared by the Bureau of Economic Analysis (BEA), which are the measures used to calculate gross domestic income (i.e., the income equivalent of gross domestic product).
} 
The unique corporate tax regime in the United States is a potentially important factor that can result in a disconnect between the growth of corporate profits and that of the economy. In deciding whether to invest in a project, managers compare the marginal benefits of the investment to its marginal costs. Taxes influence these investment decisions because they affect the costs of investments and a project's net present value (Hall and Jorgensen 1967; Romer and Romer 2010). Tax policy can affect allocation of capital, as well as the shifting of income to lower tax jurisdictions (Hines 1997; Grubert and Mutti 1991; De Mooij and Ederveen 2003; Klassen and Laplante 2012). Therefore, if the corporate income tax rate in the United States is relatively higher than that in other countries, firms have incentives to reduce the after-tax costs of investments by diverting investments to jurisdictions with lower corporate taxes. This decision can result in corporate profits not translating into subsequent domestic investments, which can contribute to the disconnect between corporate performance and economic growth.

Additionally, the tax treatment of foreign profits of U.S. multinationals provides an incentive for these firms to invest abroad. Under U.S. tax law, multinational firms must pay taxes on foreign profits at a rate equal to the U.S. tax rate upon repatriation of the earnings to the United States, and they receive a credit for foreign taxes paid on those earnings. For financial reporting purposes, under U.S. GAAP a deferred tax liability is recognized because of the temporary difference created under this regime. However, a multinational firm can designate the foreign earnings to be "permanently reinvested" under APB Opinion No. 23 to defer recognizing the residual U.S. tax. ${ }^{2}$ Thus, the corporate tax regime in the United States is incentivizing firms to

\footnotetext{
${ }^{2}$ Permanently reinvested earnings are earnings from foreign subsidiaries of U.S. multinational firms that have been invested abroad and that managers intend to reinvest indefinitely or that managers intend to remit in a tax-free liquidation (Oler, Shevlin, and Wilson 2007). Following FASB Accounting Standards Codification, APB 23 is included in Topic 740-10-25.
} 
invest these profits abroad or hold them as cash. ${ }^{3}$ This incentive, in turn, could contribute to the disconnect between U.S. corporate performance and economic growth.

In contrast, U.S. corporations can take advantage of relatively lower tax rates abroad to maximize shareholder wealth, resulting in wealth effects for their shareholders. These wealth effects can impact components of economic growth (e.g., consumption), resulting in higher growth of the overall economy (Poterba 2000). Consistent with wealth effects contributing to economic growth, we find that during our sample period aggregate stock returns and aggregate dividends (which take into account share repurchases and equity issuances) are associated with one quarterahead consumption and overall economic growth. Hence, the negative investment effect on economic output could be offset by the positive consumption effect. Moreover, it is not obvious whether the effect of relatively higher U.S. taxes on domestic investments is large enough to have macroeconomic consequences (Hanlon and Heitzman 2010). Therefore, whether the U.S. tax regime can impact the relation between growth in corporate profits and overall economic growth is an empirical question. We test this question by exploiting variations in the U.S. corporate income tax rate relative to other countries over time.

We conduct our empirical analyses during the period from 1975:Q1 to 2013:Q4 using aggregated quarterly data from the Bureau of Economic Analysis (BEA). Growth in corporate profits, on average, is higher than economic growth during our sample period. Specifically, the quarterly growth rate of national corporate profits is $2.28 \%$ compared to $1.53 \%$ for Gross National Product (GNP). However, the relation between corporate profit growth and economic growth in the United States depends on the U.S. corporate income tax rate relative to that of the other OECD

\footnotetext{
${ }^{3}$ Graham, Hanlon, and Shevlin (2010) reports in a survey of tax executives that $48 \%$ of respondents of publicly traded firms with foreign earnings consider the accounting deferral of tax on foreign earnings allowed under APB 23 to be an important factor in the decision to invest abroad.
} 
countries. ${ }^{4}$ We find that as the difference between the U.S. tax rate and the average tax rate of the OECD countries increases, the difference between the growth in corporate profits and the overall economy also increases. When the difference between the U.S. tax rate and the average OECD rate is below its time-series median, the growth in corporate profits exceeds that of the overall economy, on average, by $0.50 \%$ each quarter. Whereas, the difference between the growth rates of corporate profits and the economy increases, on average, to $0.99 \%$ each quarter when the difference between the U.S. tax rate and the average OECD rate is above its time-series median. The widening of the difference in the growth rates is economically significant as the average quarterly growth rates of national corporate profits and GNP are $2.28 \%$ and $1.53 \%$, respectively, during our sample period. This result is robust whether using domestic corporate profits or national corporate profits, which adds foreign earnings of domestic firms to domestic corporate profits.

To better understand the disconnect between corporate performance and economic growth, we examine the relation between corporate profit growth and growth in quarter-ahead domestic investments. We find that as the difference between the U.S. tax rate and the average tax rate of the OECD countries increases, fewer corporate profits are converted into subsequent domestic investments. During the period when the difference between the U.S. tax rate and the average OECD rate is below (above) its time-series median, a 1\% increase in corporate profits is associated with a $0.24 \%(0.03 \%)$ increase in one-quarter ahead domestic investments. The same pattern is observed in total repatriations of foreign earnings made by U.S. multinationals: As the difference between the U.S. corporate tax rate and the average rate of OECD countries rises, repatriations by

\footnotetext{
${ }^{4}$ Our analyses are based on the comparison of the U.S. statutory tax rate to the average OECD statutory tax rates. It is a possibility that the tax burden on corporations has not changed despite the changes in the statutory tax rates as the tax burden also depends on the tax base. That is, if the OECD countries broadened their tax bases, then comparing statutory tax rates in the United States to those of the OECD countries can lead to misleading inferences. However, Gropp and Kostial (2000) reports that the developments in effective tax rates in the OECD countries mirror those of statutory rates.
} 
U.S. firms fall. The repatriations by U.S. multinational firms are lower by $16 \%$ when the difference between the U.S. tax rate and the average OECD rate is above its time-series median.

Next, we use the American Jobs Creation Act of 2004 (AJCA) as a shock to establish the effect of variations in the U.S. tax rate on the relation between growth in corporate profits and the economy. The AJCA temporarily lowered U.S. multinationals' tax cost of repatriating foreign earnings from $35 \%$ to $5.25 \%$. Identifying the effects of tax changes on corporate behavior and the overall economy can be a significant challenge because factors that give rise to tax changes are also correlated with economic output and the performance of corporations (e.g., Hassett and Hubbard 2002; Hanlon and Heitzman 2010), but, using the narrative record of the history motivating the AJCA, Romer and Romer (2010) concludes that the shock of the AJCA is rather exogenous to other macroeconomic factors affecting economic output and corporate performance.

Prior literature has found mixed evidence on the relation between the AJCA and firm-level investment decisions. ${ }^{5}$ The advantage of examining the AJCA at the macroeconomic level is that, if companies repatriate earnings, these funds will flow into the economy irrespective of whether firms make investments domestically or distribute them to investors. This allows us to examine the effect of the AJCA on overall economic activity. We find that contemporaneous aggregate repatriations, one-quarter-ahead aggregate domestic investment growth, aggregate personal consumption growth, and economic growth increased significantly during the quarters when the

\footnotetext{
${ }^{5}$ Blouin and Krull (2009) finds that firms that chose to repatriate had limited domestic investment opportunities and that dividends and repurchases by these firms increased significantly during the act. Dharmapala, Foley, and Forbes (2011) reports that repatriations did not increase domestic investment, employment, or R\&D; instead they were associated with an increase in shareholder payouts. Faulkender and Petersen (2012) divides repatriating firms based on capital constraints and finds that only capital constrained U.S. multinationals took advantage of the AJCA to finance domestic investments using repatriated foreign earnings. Blouin, Krull, and Schwab (2014) reports that a small subset of U.S. firms receiving an incremental benefit from the domestic production activities deduction reduced shareholder payouts. Using the AJCA as a shock to firm-level investment opportunities on multinational companies, Edwards, Kravet, and Wilson (2015) finds that the AJCA reduced the effect of suboptimal investment by firms with cash "trapped" abroad.
} 
AJCA reduced the tax cost of repatriating foreign earnings. On average, the AJCA resulted in increases of $58 \%$ in repatriations, $2 \%$ in one-quarter-ahead domestic investments, $0.39 \%$ in onequarter-ahead aggregate personal consumption growth, and $0.67 \%$ in one-quarter-ahead GDP. This evidence suggests that a reduction in the relative U.S. tax rate via the AJCA contributed to overall economic growth, and that tax rates affect the decision to repatriate foreign earnings and invest domestically, factors that have contributed to the disconnect between corporate profit growth and economic growth.

To provide additional support for our findings, we conduct two more tests. First, we compare the relation between corporate profits and economic growth in the United States to this relation in Japan and the United Kingdom. While these three developed economies are arguably similar, they have starkly different tax structures. Japan's corporate tax rate has been higher than the OECD average and higher than the U.S. rate for most of the last 20 years. Alternatively, the corporate tax rate in the United Kingdom has been much lower than that in the United States and has very closely followed the decline in the rate of the other OECD countries. If higher tax rates contribute to the disconnect between corporate profits and economic growth, then we should also observe a similar disconnect for Japan but not for the United Kingdom. ${ }^{6}$ The evidence is consistent with these conjectures.

Second, we compare the changes in financial asset holdings of industries considered "mobile" for tax purposes (De Simone and Stromberg 2013) to other industries. ${ }^{7}$ We conjecture that to the extent firms in mobile industries have limited investment opportunities abroad, we

\footnotetext{
${ }^{6}$ Both Japan and United Kingdom have changed their treatment of earnings made abroad by domestic companies. In 2009 (2010), Japan (the United Kingdom) moved from a worldwide taxation system to a territorial system. We find that in both countries, domestic investment growth increases after the change, suggesting that companies are investing more of their profits domestically after the tax system changes from a worldwide tax system to a territorial one.

${ }^{7}$ Firms in mobile industries are able to transfer profits to low jurisdictions to reduce their tax burden, but they cannot repatriate these profits to either make domestic investments or distribute dividends to shareholders without incurring tax on the repatriated earnings.
} 
should observe a significantly larger increase in financial asset holdings (cash and short-term marketable securities) of firms in these industries when the U.S. tax rate is higher than the OECD tax rate. We find evidence consistent with our prediction.

It is important to note that we do not claim that relatively higher U.S. corporate tax rates are the only reason for the disconnect between the growth in corporate profits and the growth in the overall economy. In a global economy, corporations will structure their operations to exploit opportunities to grow and create value around the world. Hence, in our multivariate tests, we control for numerous macroeconomic factors that could influence the relation between corporate profits and the overall U.S. economy. ${ }^{8}$ Further, we triangulate our evidence by employing a variety of tests that take advantage of a tax shock, and cross-sectional and cross-country differences. Overall, our evidence suggests that the U.S. tax regime is one crucial factor contributing to the observed disconnect between the growth rate of corporate profits and that of the U.S. economy.

We make several contributions to the literature by providing evidence of the impact of cross-country differences in tax policies on the relation between corporate profits and the macroeconomy. First, while prior studies document the effect of taxes on investments, the evidence does not allow one to conclude whether the effect of relatively higher U.S. taxes on firmlevel domestic investments is large and systematic enough to have macroeconomic consequences (Hanlon and Heitzman 2010). Further, wealth effects at the aggregate level can offset the negative effects of lower investments on overall economic growth. We systematically document that the U.S. tax regime has implications for the relation between corporate profits and overall economic

\footnotetext{
${ }^{8}$ The factors that we control for include globalization, technological innovations, productivity changes, currency fluctuations, foreign investment opportunities, the corporate environment, interest rates, recessions, the 2007-2009 financial crisis, and income inequality in the United States.
} 
growth. We show that fewer corporate profits translate into subsequent economic growth when the U.S. corporate income tax rate is higher relative to the average of the other OECD countries.

Second, we build on the literature that has examined the economic consequences of the AJCA by documenting the effect of the AJCA at the macroeconomic level. Firm-level endogeneity has led to conflicting conclusions about the impact of the AJCA on the U.S. economy since the decision to repatriate and reinvest is correlated with many variables at the firm level (Faulkender and Petersen 2012), and to date there is little evidence suggesting that provisions in the AJCA spurred domestic investment (Blouin et al. 2014). By examining this shock in the aggregate, we are able to avoid the endogenous firm characteristics that have led to conflicting results in the literature. We show that the AJCA resulted in an increase in subsequent aggregate domestic investments, aggregate personal consumption growth, and U.S. economic growth.

Finally, we contribute to the debate over the costs and benefits of a territorial versus worldwide tax system. Using data from Japan, we document that a change from a worldwide tax system to a territorial tax system is associated with an increase in the amount of corporate profits translating into subsequent domestic investments. Currently, the United States is deliberating reforming its tax code. We provide direct evidence to evaluate the expected consequences of decreases in the corporate tax rate and changes from a worldwide tax system to a territorial one on domestic investment and economic growth.

\section{Taxes, corporate profits, and economic growth}

Several prior studies have examined the relation between taxes and economic growth. However, the empirical evidence of the effect of taxes on economic growth is, at best, mixed (e.g., Huang and Frentz 2014). Arnold et al. (2011) and Mertens and Ravn (2013) document that higher corporate taxes are associated with lower economic growth, whereas other studies find that tax 
policy is an ineffective tool to spur economic growth (e.g., Mendoza et al. 1997; Agell et al. 2003). ${ }^{9}$ We extend this literature by investigating how taxes in general and the relative U.S. tax rate in particular impact the relation between corporate profits and future economic growth.

A clear theoretical relation exists between taxes and investment decisions. Investments will be made only when the marginal benefit of the investment exceeds the marginal cost, and taxes impact the amount and uncertainty of this net present value calculation. Hall and Jorgenson (1967) shows that taxes increase the cost of investment, reducing the likelihood of investing, while tax credits have the opposite effect. Slemrod (1992) argues that firms respond to taxation through the timing of their economic transactions, accounting alterations, and real decisions.

Despite this theoretical connection, economists have struggled to document a link between tax changes and investment in the aggregate, what Hines (1998) called "one of the major puzzles in the empirical investment literature." Hassett and Hubbard (2002) suggests that endogeneity makes it difficult to isolate the effects of taxes on investment using time-series data since several aggregate variables move together over the business cycle. In summarizing this issue, Hanlon and Heitzman (2010) states that it is likely that a change in tax rates is in response to other macroeconomic factors that could also impact investments. In addition, the authors argue, controlling for the effect of contemporaneous non-tax shocks on investments poses other challenges, and it is difficult to completely rule out their effects. In the cross section, on the other hand, some empirical studies (Hassett and Hubbard 2002; Hassett and Newmark 2008) find the expected negative relation between investments and taxes, but drawing macroeconomic inferences from these studies is difficult (Hanlon and Heitzman 2010).

\footnotetext{
${ }^{9}$ A recent interesting study by Shevlin, Shivakumar and Urcan (2016) investigates the effect of tax avoidance on future economic growth.
} 
To mitigate the effects of these confounding factors, Romer and Romer (2010) uses a unique strategy to isolate the effects of tax changes on macroeconomic variables. The study examines the narrative record of tax changes and separates the reasons for these changes into four categories: (1) offsetting a shift in government spending; (2) offsetting another factor affecting output in the near future; (3) addressing an inherited budget deficit; and (4) achieving long-run goals like higher growth or increased fairness. Categories (1) and (2) are correlated with other developments affecting output, and therefore cannot be used to estimate the effects of tax changes on output, but categories (3) and (4), according to the authors, are unlikely to be systematically related to other factors impacting output in the short and medium run. Romer and Romer (2010) uses tax changes that fall into the latter two categories as fiscal shocks and shows that tax increases have a large negative effect on investment, while tax cuts have positive and persistent investment effects.

Given that tax policy directly affects the net returns from investments, investment location decisions are strongly influenced by differences in tax costs across countries. ${ }^{10}$ Studies have documented that the average tax elasticity of investment is negative, suggesting that an increase in host countries' tax rates results in a decrease in U.S. foreign direct investment in that jurisdiction (Grubert and Mutti 1991; Hines and Rice 1994). ${ }^{11}$ Altshuler, Grubert, and Newlon (2000) reports that investment location decisions have become more sensitive to tax rates over time and finds that

\footnotetext{
${ }^{10}$ Dyreng and Lindsey (2009) finds that, on average, U.S. firms with operations in tax havens have lower tax bills. When examining Delaware, a domestic tax haven, Dyreng, Lindsey, and Thornock (2013) provides evidence that taxes affect the decision to locate subsidiaries in the state, and parent firms that do locate their subsidiaries there receive substantial tax savings.

${ }^{11}$ See Shackelford and Shevlin (2001) for a review of a related literature that examines global tax planning by U.S. multinationals with regard to capital structure. Maydew (2001) provides a discussion of Shackelford and Shevlin (2001).
} 
the elasticity of real capital to after-tax returns of large U.S. manufacturing multinational companies increased from 1.5 in 1984 to 2.8 in 1992.

Further, the tax treatment of foreign income provides firms with discretion over the timing of reporting taxable income and/or book income (Krull 2004; Shackleford, Slemrod, and Sallee 2011). Thus, firms that value flexibility in tax and financial reporting have incentives to invest outside the United States (Shackelford, Shaviro, and Slemrod 2010). The tax rules do not require U.S. parent companies to pay any U.S. taxes on the earnings of their foreign subsidiaries until the profits are repatriated to the United States as dividends. ${ }^{12}$ U.S. GAAP requires that a deferred tax liability be recognized because a temporary difference is created since foreign earnings will only be taxed when they are repatriated. However, a multinational firm can designate the foreign earnings to be permanently reinvested under APB 23 to defer recognizing the residual U.S. tax. By electing to designate foreign income as permanently reinvested, the U.S. parent company can reduce its income tax expense and report higher after-tax earnings for the current year if the tax rate in the host country of the foreign subsidiary is lower than that in the United States. This increase in earnings is a result of the recognized tax expense being made up only of the foreign taxes paid at the lower foreign income tax rate.

Accounting deferral of taxes on foreign earnings allowed under APB 23 has also proved to be an important factor in the decision to make investments abroad rather than in the United States. Several studies provide firm-level evidence showing that the tax treatment of foreign earnings encourages firms to invest abroad and hold more cash and financial assets (Hartman 1985; Foley, Hartzell, Titman, and Twite 2007; Graham, Hanlon, and Shevlin 2010; Blouin, Krull, and Robinson 2012; Klassen and Laplante 2012; Blouin, Krull, and Robinson 2014; Klassen, Laplante,

\footnotetext{
${ }^{12}$ When the foreign earnings are repatriated as dividends, the parent companies pay the "residual" U.S. tax, which is the U.S. tax due net of foreign tax credits for taxes paid to foreign governments.
} 
and Carnaghan 2014). ${ }^{13}$ “Trapped cash," as cash held abroad for tax reasons is often called, impacts investing decisions both at home and abroad. Hanlon et al. (2015) finds that trapped cash is positively related to increased foreign acquisitions, and that the market reaction to these acquisitions is negatively associated with the level of trapped cash. Relatedly, Edwards et al. (2015) finds a negative relation between the profitability of foreign acquisitions and the amount of trapped cash. The AJCA, which the authors use as a shock to this relation, significantly reduces this effect by allowing firms to repatriate foreign earnings held as cash abroad at a much lower tax cost. Finally, Blouin et al. (2014) explores the impact of trapped cash on domestic investment. In addition to providing evidence that most permanently reinvested earnings (PRE) abroad are held in financial assets, the study finds a negative relation between the ability of multinational firms to take advantage of domestic investment opportunities and the level of PRE held in cash by these firms.

In summary, the direct effect of taxes on the after-tax return from investments and the tax treatment of foreign earnings provide incentives to U.S. companies to invest in jurisdictions outside the United States and discourages firms from repatriating foreign profits when the tax costs in the United States are relatively higher. Hence, when the United States is at a disadvantage relative to other jurisdictions due to a higher U.S. corporate tax rate, fewer corporate profits are likely to be channeled to subsequent domestic investments since companies have incentives to invest outside the United States and not repatriate foreign earnings. As a result, the relation

\footnotetext{
${ }^{13}$ Klassen and LaPlante (2012) shows that, along with the differences in tax rates between jurisdictions, regulatory costs of income shifting also affect a firm's decision to shift income between jurisdictions. They find that U.S. corporations have become more active recently at shifting income outside of the United States as regulatory costs of shifting have changed.
} 
between corporate profits and economic growth may shift as lower growth in domestic investments results in lower contemporaneous growth in the economy.

Alternatively, there are several reasons that can counteract the influence of the investment channel described above on the relation between corporate profits and economic growth. First, while prior studies provide firm-level evidence that relatively higher U.S. taxes and the tax treatment of foreign earnings have incentivized domestic firms to invest abroad or hold earnings outside the United States, these effects may not be large enough to have macroeconomic consequences, or they may be diversified when aggregated to the macroeconomic level such that the relatively higher U.S. taxes have not altered the relation between the growth in corporate profits and economic growth. For instance, Faulkender and Petersen (2012) reports that how a firm used the funds repatriated under the AJCA depended on whether the repatriating firm was financially constrained. Financially constrained firms, which were responsible for only $27 \%$ of the total funds repatriated under AJCA, used $78 \%$ of the funds they repatriated to increase investments. On the other hand, unconstrained firm, which accounted for a significant majority of the total funds repatriated under AJCA, did not use the repatriated funds for investments. Hence, it is unclear whether a reduction in repatriation taxes under AJCA had a large enough effect on aggregate investments at the macroeconomic level. By conducting our analyses at the aggregate macroeconomic level, we are able to avoid firm-level endogeneity and assess the macroeconomic impact of tax policy.

Second, U.S. corporations can maximize shareholder wealth by taking advantage of relatively lower taxes abroad, resulting in wealth effects for their shareholders in the United States. Prior studies show that wealth effects can alter consumption (see Poterba (2000) for a review of this literature), which can contribute to overall economic growth. Poterba (2000) argues that, in 
the United States, a 3\% marginal propensity to consume out of wealth is reasonable. However, even such low estimates of the marginal propensity to consume can have significant aggregate consumption and demand effects: A 3\% marginal propensity to consume out of stock market wealth accumulation during 1995-1999 is associated with an increase in aggregate demand of roughly $2 \%$ of GDP in 2000 . Consistent with the wealth effects channel, we find that during our sample period aggregate stock returns and dividends are significantly associated with one-quarter ahead personal consumption and overall economic growth (as documented in Table A4). Therefore, whether and how the U.S. tax regime impacts the relation between growth of profits of U.S. corporations and economic growth is an empirical question as the investment and the wealth channels have offsetting effects on overall economic output.

\section{Sample and empirical analysis}

\subsection{Sample}

The sample for our primary analyses consists of quarterly aggregated macroeconomic data from 1975 to 2013 obtained from the BEA. We use two measures of economic growth, GDP and GNP, and two measures of corporate profits, domestic corporate profits and national corporate profits. GDP is the value of all goods and services produced in the United States, while GNP is the value of all goods and services produced by U.S. residents and firms, regardless of where they are produced. Corporate profits, as defined by the BEA, are measures of the income of all corporations that are required to file corporate tax returns (Bureau of Economic Analysis 2014). Domestic corporate profits include profits made within the United States, while national corporate profits include domestic and foreign profits of U.S. companies. Thus, national corporate profits include foreign profits of U.S. companies. Whereas, domestic corporate profits exclude profits made 
abroad by domestic companies. Both national and domestic corporate profits are adjusted for changes in the book value of inventory and capital. These adjustments allow for a more direct examination of changes in actual profits without the influence of book changes in assets held on the balance sheet. ${ }^{14}$

Using the BEA data rather than COMPUSTAT to measure corporate profits has several advantages. The BEA data allow us to include profits earned by public as well as private U.S. firms in our analysis. Further, using the BEA data ensures that our analysis of corporate profits and overall economic growth is not confounded by differences in measurement methodologies. That is, using BEA estimates ensures that corporate profits and economic output are measured in a consistent fashion. In contrast, aggregating firm-level profits as reported under U.S. GAAP can be problematic for our analysis because the definition and measurement methodology of corporate profits (which are also a component of total economic output) differs between the BEA and U.S. GAAP. Moreover, employing aggregate data is important since firm-level data cannot be used to reliably answer our research question because multiple channels (e.g., firms' direct investments, changes in consumption) affect the relation between corporate profits and economic growth. Finally, firm-level corporate profits estimated using U.S. GAAP include profits earned domestically and in international jurisdictions. Whereas, the BEA data allows us to analyze the relation between domestic (national) corporate profits and domestic (national) economic growth separately.

\footnotetext{
${ }^{14}$ The inventory adjustment removes gains or losses from holding inventory that is valued at historical cost. To do this, the BEA converts the valuation of withdrawals from inventory based on current and historical costs to a currentcost basis. The capital adjustment first converts depreciation values to values based on useful lives and empirically based depreciation patterns. Then, it converts depreciation measures to current-cost values like in the inventory adjustment.
} 
Gross Domestic Product (GDP), Gross National Product (GNP) and components of these variables (corporate profits, gross private domestic investment, government spending, employee compensation, and consumption) are quarter-over-quarter seasonally adjusted percent changes. A detailed description of all the variables is provided in the Appendix. We also collect data on the percentage of foreign earnings of U.S. firms that are repatriated through dividends and withdrawals, and those that are reinvested abroad from the Bureau of Economic Analysis. Quarterly data on repatriations from the BEA is available from 1981.

We gather the quarterly yields on 10-year and 1-year Treasuries from CRSP. Quarterly value-weighted aggregate stock returns are downloaded from Kenneth French's website. ${ }^{15}$ We follow the National Bureau of Economic Research in defining recession periods. Tax rate data on OECD countries are retrieved from the OECD website from 1981 onwards. Prior to 1981, these data are collected from the Price Waterhouse \& Co. Taxes in 80 Countries publications for the years 1975 to 1980. GDP data on OECD countries are also retrieved from the OECD website. Our measure of inequality, the percentage of total income earned by the wealthiest $1 \%$ of U.S. citizens, is retrieved from The World Top Income Database. Quarterly output per hour for all non-farm businesses, our measure of productivity, is retrieved from the Bureau of Labor Statistics. Accounting data come from the Compustat quarterly dataset. Quarterly default spread, measured as the difference between the yields on Aaa and Baa corporate bonds, and the weighted average of the foreign exchange value of the U.S. dollar against a subset of currencies that circulate widely are retrieved from FRED, the Federal Reserve Bank of St. Louis. Finally, the sample for our main analyses is restricted to the period 1975:Q1 to 2013:Q4 because of tax data availability.

\footnotetext{
${ }^{15}$ French's data are available at http://mba.tuck.dartmouth.edu/pages/faculty/ken.french/data_library.html.
} 


\subsection{Growth in corporate profits and the economy}

\subsubsection{Descriptive statistics}

We begin our analyses by examining the relation between the growth in corporate profits and growth in the economy. The descriptive statistics presented in Table 1 Panel A examine average quarterly growth in various macroeconomic variables during several periods. The average quarterly growth rate of GNP (GDP) is $1.53 \%$ (1.54\%) over the full sample period compared to $2.28 \%(2.46 \%)$ for national (domestic) corporate profits, which suggests a disconnect between corporate profit growth and economic growth in our sample period.

The descriptive statistics provide evidence that the difference in the growth rates of corporate profits and the overall economy is greater when the difference between the tax rates of the United States and OECD is above the median difference (see Figure 1 for a plot of the corporate tax rate of the United States and the average corporate tax rate for the OECD countries during our sample period). When the difference between the tax rate in the United States and the average OECD tax rate is less than the median difference $(2.60 \%)$, national (domestic) corporate profits, CPN (CPD), grow, on average, by $2.47 \%$ (2.67\%) each quarter and GNP and GDP average growth is $1.97 \%$. During the period in which the difference between the U.S. tax rate and that of the OECD average is above the median difference, corporate profits growth diverges more from growth in the overall economy: $\mathrm{CPN}(\mathrm{CPD})$ grows at an average rate of $2.11 \%(2.26 \%)$ each quarter, whereas the GNP (GDP) average growth rate is $1.12 \%(1.12 \%) .{ }^{16}$ The same pattern is observed in the relation between corporate profit growth and the growth of domestic investments (INV). When the

\footnotetext{
${ }^{16}$ In untabulated results, we find that when the U.S. tax rate is below the average OECD tax rate, overall economic growth is higher than corporate profits growth. Specifically, in our sample period, we find that in 32 quarters, the U.S. tax rate is below the average OECD tax rate. In these quarters, growth in national (domestic) corporate profits is 1.37 $\%(1.33 \%)$ which is lower than the GNP and GDP growth rates of $1.73 \%$.
} 
difference in the tax rates is below the median, the growth in CPN and INV are more closely aligned $-2.47 \%$ per quarter for CPN versus $1.98 \%$ for INV. These growth rates diverge significantly when the difference in the tax rates is above the median and the after-tax return on investments abroad exceeds that of investments in the United States. During the period when the difference in the tax rates is above the median difference, INV grows at only $1.15 \%$ per quarter, whereas CPN grows on average by $2.11 \%$ each quarter.

In Panel B, we estimate multivariate regressions where we regress the growth in domestic corporate profits (CPD), the value of the U.S. tax rate minus the average OECD rate (Tax_diff), and the interaction of the two on the growth in the components of GDP. We find that only the growth in domestic investments (INV) has a significant and positive relation with CPD (Column (1) reports a coefficient of 0.11 on $\mathrm{CPD}$, which is significant at the $5 \%$ level, and Column (2) reports a coefficient of 0.23 on $\mathrm{CPD}$, which is significant at the $1 \%$ level). INV also is the only component of GDP that has a significant relation with the interaction of CPD and Tax_diff, with a coefficient of -1.70 , significant at greater than $1 \%$ (see Column (2)). Given that we fail to find any empirical relations between the growth in other components of GDP and the growth in corporate profits, going forward we focus on domestic investments in our main analysis.

Overall, Table 1 provides preliminary evidence in support of the claim that the relatively higher U.S. tax rate has contributed to the disconnect between the growth in corporate profits and growth in the overall economy by decreasing the after-tax return on domestic investments, resulting in fewer corporate profits being translated into domestic investments. 


\subsubsection{Multivariate analysis}

Next, using multivariate regressions, we examine the relation between corporate profits and economic growth, as well as the impact of tax rates on this relation. To do so, we investigate the association between the growth in domestic, as well as national corporate profits, and GDP and GNP. ${ }^{17}$ Through the examination of the association between overall economic growth and corporate profits growth, we attempt to capture whether the relatively higher U.S. tax rate affects the contribution of corporate profits to overall economic growth.

Specifically, we estimate regressions nested in the following models:

$\mathrm{GNP}_{\mathrm{t}+1}=\alpha+\beta_{1} \mathrm{CPN}_{\mathrm{t}}+\beta_{2} \mathrm{Tax}_{-} \operatorname{diff}_{\mathrm{t}}+\beta_{3}$ Tax_diff $_{\mathrm{t}} * \mathrm{CPN}_{\mathrm{t}}+\beta_{4} \mathrm{Crisis}_{\mathrm{t}}+\beta_{5} \mathrm{GNP}_{\mathrm{t}}+\beta_{6}$ Term $_{\mathrm{t}}+\beta_{7} \mathrm{DEF}_{\mathrm{t}}$ $+\beta_{8}$ T-note $_{t}+\beta_{9}$ Ret $_{t}+\beta_{10}$ Recession $_{t}+\beta_{11}$ Openness $_{t}+\beta_{12}$ Tech $_{t}+\beta_{13}$ Productivity $_{t}+\beta_{14}$ FX $_{t}+$ $\beta_{15}$ Inv_opp $_{t}+\beta_{16}$ Ineq $_{t}+\varepsilon_{t+1}$

$\mathrm{GDP}_{\mathrm{t}+1}=\alpha+\gamma_{1} \mathrm{CPD}_{\mathrm{t}}+\gamma_{2} \mathrm{Tax}_{-} \operatorname{diff}_{\mathrm{t}}+\gamma_{3} \mathrm{Tax}_{-} \operatorname{diff}_{\mathrm{t}} * \mathrm{CPD}_{\mathrm{t}}+\gamma_{4} \mathrm{Crisis}_{\mathrm{t}}+\gamma_{5} \mathrm{GDP}_{\mathrm{t}}+\gamma_{6} \mathrm{Term}_{\mathrm{t}}+\gamma_{7} \mathrm{DEF}_{\mathrm{t}}$ $+\gamma_{8}$ T-note $_{t}+\gamma_{9}$ Ret $_{t}+\gamma_{10}$ Recession $_{t}+\gamma_{11}$ Openness $_{t}+\gamma_{12}$ Tech $_{t}+\gamma_{13}$ Productivity $_{t}+\gamma_{14} \mathrm{FX}_{\mathrm{t}}+$ $\gamma_{15}$ Inv_opp ${ }_{t}+\gamma_{16}$ Ineq $_{t}+\varepsilon_{t+1}$

where GDP (GNP) is the quarterly percentage change in gross domestic (national) product. CPD $(\mathrm{CPN})$ is the quarterly growth rate in domestic (national) corporate profits. Tax_diff is the difference between the statutory U.S. corporate income tax rate and the average statutory corporate income tax rate of the OECD countries. The interaction between Tax_diff and CPD (CPN) is our variable of interest.

We do not claim that the differential tax rates are the only factor impacting the relation between corporate profits and economic growth. Hence, we include several variables to control for other

\footnotetext{
${ }^{17}$ When examining corporate profits, we conduct our tests using both domestic and national corporate profits to provide robust evidence for our predictions. While the shifting relation between domestic corporate profits and economic growth is less direct in our setting, when taxes are lower abroad, firms not only have an incentive to keep foreign profits abroad but also to invest domestic profits abroad.
} 
macroeconomic factors that could affect the relation between corporate profits and economic growth. To control for the impact of the 2007-2009 financial crisis, we include Crisis, a dummy equal to 1 from Q4:2007 to Q1:2009, and 0 otherwise. Kothari, Lewellen, and Warner (2014) finds that interest rates and default spreads are predictive of next-quarter investments. Therefore, we control for the effects of aggregate interest rates and changes in default risk by including three proxies: Term, the quarterly difference between returns on 10-year and 1-year Treasuries; DEF, the quarterly default spread; and T-note, the quarterly yield on the 10-year Treasury note. Ret, quarterly value-weighted stock returns, controls for the impact of the corporate environment. Recession is an indicator equal to 1 if the U.S. economy was in a recession during the quarter, as defined by the National Bureau of Economic Research, and 0 otherwise, and is included to control for financial downturns.

Increased international trade can have an impact on how income is distributed (Giovannoni, Lu, Nguyen, and $\mathrm{Xu}$ 2014). As international trade increases in an economy, corporate decisions about how to distribute income and where to invest may be effected, regardless of the tax environment. To control for the effects of globalization, we follow Krugman (2008) in calculating quarterly Openness of the United States to international trade as the sum of aggregate imports and exports, scaled by GDP. Tech is the ratio of quarterly INV to GDP and is used as a proxy for technological changes in the economy (Greenwood, Hercowitz, and Krussel 1997) that could influence how and where firms choose to invest. Following Guscina (2006), we measure economywide productivity change (Productivity) as the Bureau of Labor Statistics' quarterly measure of output per hour for all non-farm businesses. We include this variable to control for how the shifting role of labor in the U.S. economy could impact domestic economic growth. FX is the weighted average of the foreign exchange value of the U.S. dollar against a broad index of currencies that 
circulate widely, and is meant to control for the impact of currency fluctuations. Foreign investment opportunities available to U.S. firms have increased over time, and Nessa, Wilson, and Shevlin (2015) report that investors value foreign earnings based on future investment opportunities available to firms. Accordingly, Inv_opp is a proxy for investment opportunities abroad and is the average of the quarter-over-quarter average GDP growth rates for all OECD countries except the United States. Finally, we include Ineq, the percentage of total U.S. income going to the wealthiest $1 \%$ of residents, to control for the impact of rising inequality on the economy as a whole.

Table 2 provides evidence on the relation between one-quarter-ahead economic growth and contemporaneous corporate profits growth. In Panel A (B), economic activity is measured using GNP (GDP). The coefficient on CPN in Panel A, Column 1, is a statistically significant 0.03 , suggesting that, on average, growth in corporate profits and growth in the economy are positively associated during our sample period. In Columns 2 through 5 , we examine and compare the change in this relation using Tax_diff, which captures the difference in the U.S. tax rate and the OECD rate. In Column 2 of Panel A, the coefficient on CPN is 0.05 and statistically significant. However, as the difference between the corporate tax rate in the United States and the average OECD rate increases, the positive association between economic and corporate profit growth declines significantly. The coefficient on the interaction of Tax_diff and CPN is -0.31 and statistically significant.

This decline is economically significant as well. To estimate the economic significance, we use an indicator classification for the tax regime, which facilitates interpretation of the regression coefficients. The results of this analysis are reported in Panel A of Table A1 in the Appendix. The tax regime indicator variable, TaxDum, equals 1 when the difference between the 
U.S. tax rate and the average OECD rate is above the median difference of $2.60 \%$, and 0 otherwise. We find that, when the tax rate difference is below its time-series median (i.e., TaxDum $=0$ ), a $1 \%$ increase in the growth of corporate profits is associated with $0.06 \%$ increase in one-quarter ahead economic growth. When the tax rate difference is above its time-series median (i.e., TaxDum $=1$ ), a $1 \%$ increase in corporate profits growth only contributes $0.01 \%$ to one-quarter ahead economic growth. The above documented pattern is robust to controlling for the other macroeconomic factors listed above (see Columns 3-5).

In Panel B of Table 2, we use GDP as the dependent variable and corporate profits are defined as domestic corporate profits. Consistent with the results of Panel A, the evidence in Panel B suggest that the relation between corporate profit growth and economic growth is altered based on the U.S.-OECD tax differential. In all models, the growth in domestic corporate profits is positively associated with growth in GDP. However, when we interact Tax_diff with CPD, the association between the interaction term and GDP is negative and significant in all columns

In summary, the evidence in Table 2 suggests that the difference between the corporate tax rate in the United States and the average OECD corporate tax rate changes the relation between U.S. corporate profit growth and economic growth. As the U.S. tax rate increases relative to the OECD rate, fewer corporate profits are translating into overall economic growth. Further, the evidence is suggestive of the relatively higher U.S. tax rate deterring future investments and repatriations in amounts significant enough to have macroeconomic consequences and that this effect dominates the wealth effects channel. ${ }^{18}$

\footnotetext{
${ }^{18}$ To ensure that our results are not driven solely by the influence of the AJCA, in untabulated analysis, we repeat all of our main tests excluding Q4:2004 to Q4:2005. Our results are robust to the exclusion of this period.
} 


\subsection{Corporate profits and domestic investments}

In this section, we attempt to determine an underlying channel through which the relatively higher U.S. tax rate has contributed to the disconnect between economic growth and corporate profit growth. We conjecture and test whether U.S. companies direct fewer profits towards subsequent domestic investments as the U.S. tax rate increases relative to OECD tax rate. ${ }^{19}$ To test this conjecture, we estimate regressions nested in the following equation:

$\mathrm{INV}_{\mathrm{t}+1}=\alpha+\delta_{1} \mathrm{CPD}_{\mathrm{t}}+\delta_{2} \mathrm{Tax}_{-} \operatorname{diff}_{\mathrm{t}}+\delta_{3} \mathrm{Tax}_{-} \operatorname{diff}_{\mathrm{t}} * \mathrm{CPD}_{\mathrm{t}}+\delta_{4} \mathrm{Crisis}_{\mathrm{t}}+\delta_{5} \mathrm{INV}_{\mathrm{t}}+\delta_{6} \mathrm{GDP}_{\mathrm{t}}+\delta_{7} \mathrm{Term}_{\mathrm{t}}+$ $\delta_{8} \mathrm{DEF}_{\mathrm{t}}+\delta_{9}$ T-note $_{\mathrm{t}}+\delta_{10}$ Ret $_{\mathrm{t}}+\delta_{11}$ Recession $+\delta_{11}$ Openness $_{\mathrm{t}}+\delta_{12}$ Tech $_{\mathrm{t}}+\delta_{13}$ Productivity $_{\mathrm{t}}+\delta_{14} \mathrm{FX}_{\mathrm{t}}$ $+\delta_{15} \operatorname{Inv}_{-}$opp $_{\mathrm{t}}+\delta_{16} \operatorname{Ineq}_{\mathrm{t}}+\varepsilon_{\mathrm{t}+1}$,

where INV is the quarterly percentage growth in seasonally adjusted aggregate U.S. domestic investments. All other variables are defined as above.

The results of estimating Equation (3) are reported in Table 3. Similar to the relation between economic growth and corporate profit growth, during the full sample period growth in corporate profits is positively associated with growth in domestic investments: the coefficient on CPD is positive and statistically significant in all specifications. In Column 2 , the coefficient on the interaction between Tax_diff and CPD is a negative 1.70 and statistically significant, suggesting that the association between growth in domestic corporate profits and one-quarter ahead domestic investment growth is less positive when the U.S. tax rate is relatively higher in comparison to that of the OECD countries.

The decline in the relation between growth in domestic profits and one-quarter-ahead investments is economically significant as well. As before, we classify the tax regime using an

\footnotetext{
${ }^{19}$ Kothari, Lewellen, and Warner (2014) and Arif and Lee (2014) investigate the relation between investments and subsequent economic growth, while we focus on the relation between corporate profit growth and one-quarter-ahead growth in aggregate investments, which are included in the calculation of GDP.
} 
indicator variable, TaxDum, that equals $1(0)$ when the difference between the US tax rate and the OECD rate is above (below) the median to assist in the estimation of the economic significance. In Column 2 of Table A2 of the Appendix, the coefficient on CPD is 0.24 and coefficient on the interaction of CPD and TaxDum is -0.21 . Both are statistically significant. This suggests that a $1 \%$ increase in the growth of corporate profits is associated with an increase of $0.24 \%$ in the growth in one-quarter-ahead investments when the difference between the U.S. tax rate and the OECD rate is below its time-series median (i.e., TaxDum $=0$ ). When the tax difference is above its timeseries median, a $1 \%$ increase in corporate profits growth is associated with a $0.03 \%$ increase in one-quarter-ahead investment growth. Further, the patterns in the relation between growth in corporate profits and one-quarter-ahead investments are robust to controlling for a variety of other factors (see Columns 3-5 in Tables 3 and A2).

Taken together, the evidence in Tables 1,2, and 3 suggests that an underlying channel for the disconnect between corporate profit growth and economic growth is that fewer corporate profits are translating into subsequent private domestic investments, a component of GDP, as the U.S. tax rate increases relative to the average OECD tax rate.

\subsection{Repatriation and corporate profits}

Having established the influence of the U.S. tax rate on the relations among corporate profit growth, economic growth, and growth in investments, we turn our attention to the impact of the relatively higher taxes in the United States on the repatriation of foreign earnings. Since U.S. multinationals are required to pay incremental taxes when they repatriate foreign profits, the incentive to repatriate profits to the United States is reduced when the relative U.S. tax rate is higher than that of the country where the profits are earned. Graham, Hanlon, and Shevlin (2011) 
reports that companies care about minimizing the financial accounting tax expense along with avoiding cash taxes paid. Accordingly, we test the effect of the relative disadvantage of the U.S. tax regime on repatriations by U.S. multinationals by estimating various regressions nested in the following equation:

REPAT $_{\mathrm{t}+1}=\alpha+\varphi_{1} \mathrm{CPN}_{\mathrm{t}}+\varphi_{2} \mathrm{Tax}_{-} \operatorname{diff}_{\mathrm{t}}+\varphi_{3} \mathrm{Crisis}+\varphi_{4} \mathrm{GNP}_{\mathrm{t}}+\varphi_{5} \mathrm{Term}_{\mathrm{t}}+\varphi_{6} \mathrm{DEF}_{\mathrm{t}}+\varphi_{7} \mathrm{~T}-$ note $_{\mathrm{t}}+$ $\varphi_{8}$ Ret $_{\mathrm{t}}+\varphi_{9}$ Recession $+\varphi_{11}$ Openness $_{\mathrm{t}}+\varphi_{12}$ Tech $_{\mathrm{t}}+\varphi_{13}$ Productivity $_{\mathrm{t}}+\varphi_{14} \mathrm{FX}_{\mathrm{t}}+\varphi_{15}$ Inv_opp $_{\mathrm{t}}+$ $\varphi_{16}$ Ineq $_{t}+\varepsilon_{t+1}$,

where REPAT is the percentage of foreign profits repatriated to the United States, and all other variables are defined as above. In these regressions, our main variable of interest is Tax_diff, which we predict will have a negative coefficient. This analysis is restricted to the years 1982 to 2013 because the quarterly data on repatriation become available only after 1981.

Table 4 reports the results of estimating Equation (4). Consistent with our expectations, we find that as the difference between the U.S. corporate tax rate and the average rate of the OECD countries increases, the proportion of corporate profits that are repatriated to the United States decreases significantly. In Column 2, the coefficient on Tax_diff is -151.21 and statistically significant. Thus, the evidence in Table 4 suggests that the relatively higher U.S. tax rate has led to fewer foreign profits being repatriated. The effect of the relatively higher U.S. tax rates on repatriations is economically significant as well. In Column 2 of Table A3, using the indicator variable TaxDum, we find that repatriations are lower by $16 \%$ when the difference between the U.S. tax rate and the average OECD rate is above its time-series median. The decrease in repatriations is robust to including other potentially correlated macroeconomic factors in our models (see Columns 3-5). 


\subsection{Evidence from the American Jobs Creation Act of 2004}

In this section, we use the AJCA as a shock to the tax system to better establish the effect of the U.S. tax rate on domestic investments and repatriations, underlying mechanisms that are contributing to the disconnect between the growth in corporate profits and the growth in the economy.

The AJCA, which granted a one-time dividend received deduction of $85 \%$ on foreign earnings repatriated between October 2004 to December 2005, as well as a deduction for domestically manufactured products, has been used as an exogenous change to establish the effect of taxes on firm-level repatriations and investments (Figure 2 shows the impact of the AJCA on repatriations). However, the endogenous characteristics of firms that were or were not able to take advantage of the AJCA have led to mixed evidence of the relation between the AJCA and firmlevel investment and repatriation decisions. Blouin and Krull (2009) documents that the repatriating firms had limited domestic investment opportunities, and these firms increased dividends and repurchases significantly during the AJCA period. Dharmapala et al. (2011) finds that repatriations did not increase domestic investment, employment, or research and development, even for financially constrained firms. Instead, the repatriations were associated with an increase in shareholder payouts. Faulkender and Petersen (2012), on the other hand, classifies firms based on capital constraints and shows that capital-constrained firms did indeed take advantage of the tax reduction under AJCA to finance domestic investments using repatriated foreign earnings. Edwards et al. (2015) finds that firms with high levels of trapped cash make less profitable foreign acquisition, but the AJCA greatly reduced this effect. Blouin et al. (2014), Ohrn (2014) and Lester (2015) investigate the effect of domestic production activities deduction (DPAD) for domestically 
manufactured products on firms' payouts and investments. ${ }^{20}$ These studies find evidence suggestive of domestic investment responding positively to the DPAD and smaller and financially constrained firms responding more positively to the tax deduction.

We adopt a different approach and use the temporary reduction in the tax costs of repatriating foreign earnings under the AJCA as a shock to investigate the effect of tax rates on aggregate domestic investments, aggregate personal consumption expenditures, and repatriations. A significant benefit of examining the effect of the AJCA at the aggregate level is that we can overcome endogeneity related to firm characteristics. Faulkender and Petersen (2012) points out that the endogenous firm-level investment decision affects whether funds are repatriated and how they are spent. Observable and unobservable omitted variables can lead to conflicting conclusions about the impact of the AJCA. We argue that these firm-level decisions are inconsequential at the aggregate level. If companies repatriate their earnings, these funds will flow through the economy regardless of how each firm chooses to spend the funds (e.g., by making domestic investments or paying dividends). For instance, when repatriations are used to pay dividends, shareholders could consume more or reinvest the dividends into the economy. Therefore, whether the funds are invested internally or paid out to investors, they will contribute to economic growth. ${ }^{21}$

\footnotetext{
${ }^{20}$ The DPAD provides a $9 \%$ deduction, phased in over several years, for domestic producers Initially, the deduction is calculated as the lesser of $3 \%$ of a taxpayer's qualified production activities income, $3 \%$ of a taxpayer's taxable income, or $50 \%$ of W-2 wages paid by the taxpayer for tax years beginning in 2005 and 2006 . The deduction increases to $6 \%$ of qualified income or taxable income for tax years beginning in 2007-2009, and the full $9 \%$ from 2010 onward. More details of the DPAD can be found at http://www.lawprofessorblogs.com/taxprof/linkdocs/2005-2228-1.pdf

${ }^{21}$ To validate this conjecture, we investigate the time-series relation between aggregate dividends (which account for share repurchases and equity issuances) and one-quarter-ahead domestic investments. Appendix Table A4 presents the results. Consistent with expectations, we find that aggregate dividends are positively associated with one-quarterahead domestic aggregate investments.
} 
We estimate regressions nested in the following equation to examine the effect of an exogenous tax rate cut for the repatriation of foreign earnings offered per the AJCA on repatriations, investments, consumption, and economic growth:

$\mathrm{DV}=\alpha+\tau_{1} \mathrm{ACT}+\tau_{2}$ Crisis $+\tau_{3}$ Term $_{\mathrm{t}}+\tau_{4} \mathrm{DEF}_{\mathrm{t}}+\tau_{5} \mathrm{~T}_{\text {- }}$ note $_{\mathrm{t}}+\tau_{6}$ Ret $_{\mathrm{t}}+\tau_{7}$ Recession $+\tau_{8}$ Openness $_{\mathrm{t}}+$ $\tau_{9}$ Tech $_{\mathrm{t}}+\tau_{10}$ Productivity $_{\mathrm{t}}+\tau_{11} \mathrm{FX}_{\mathrm{t}}+\tau_{12}$ Inv_opp $_{\mathrm{t}}+\tau_{13}$ Ineq $_{\mathrm{t}}+\tau_{14} \mathrm{CP}_{\mathrm{t}}+\tau_{15}$ Economic growth $_{\mathrm{t}}+\varepsilon_{\mathrm{t}}$,

where ACT, our variable of interest, equals 1 for quarter 2004:Q4 to 2005:Q4, the period during which the AJCA allowed U.S. multinationals to repatriate foreign earnings at a reduced tax rate of $5.25 \%$, and 0 otherwise. ${ }^{22}$ Our dependent variables are contemporaneous REPAT, and quarterahead INV, Con, GDP and GNP. We predict that the coefficient on ACT will be positive in all regressions. All other variables are defined as above.

Table 5 presents the results of the effect of the AJCA on our dependent variables. As predicted, in Column 1 the coefficient on ACT is 57.75 and statistically significant. This result suggests that the provisions of the AJCA resulted in a significant increase in repatriations of foreign earnings. On average, the AJCA was associated with an economically significant increase of approximately $58 \%$ quarterly repatriations of foreign earnings. For comparison, the quarterly average percentage of foreign earnings repatriated by U.S. multinationals was 49\%. Column 2 (3) presents the results of testing the effect of the AJCA on domestic investments (personal consumption growth). On average, the AJCA is associated with an economically and statistically significant increase of $1.96 \%(0.39 \%)$ on domestic investments (domestic personal consumption

\footnotetext{
${ }^{22}$ Redmiles (2008) reports that a small percentage of U.S. firms reported repatriations in the 2006 tax year. We check the robustness of our findings by including 2006:Q1 in the AJCA period. Our inference remain unchanged.
} 
growth). ${ }^{23}$ We find similar results in Columns 4 and 5 for our measures of economic growth. ${ }^{24}$ The coefficient on ACT in Column 4 (5) is $0.67(0.64)$ and statistically significant, suggesting that during the AJCA period, quarter-ahead growth in GDP (GNP) increased, on average, by $0.67 \%$ $(0.64 \%)$. For comparison, the quarterly average growth rate of GDP and GNP is approximately $1.5 \%$ in our full sample period. ${ }^{25}$

In summary, the evidence in this section and the previous section suggests that tax incentives have causal effects on domestic investments, as well as repatriations of foreign earnings, an underlying channel contributing to the disconnect between the growth in corporate profits and growth in the overall economy in the United States.

\section{Additional analyses}

In this section, we perform several analyses to strengthen the identification of mechanisms contributing to the disconnect between corporate profits and economic growth.

\subsection{Corporate profits and economic growth in the Japan and United Kingdom}

To further rule out the alternative mechanisms that might be driving our findings, we compare the relation between corporate profits and economic growth in the United States to that in Japan and the United Kingdom. While the three developed economies are arguably similar, their corporate tax regimes have several significant differences. Japan's corporate tax rate has been higher than the OECD average and higher than the U.S. rate for most of the last 20 years. On the

\footnotetext{
${ }^{23}$ Blouin et al. (2014) reports that the joint effect of DPAD and the repatriation tax holiday provided under AJCA encouraged domestic manufacturing firms to potentially increase investments. Thus, the observed increase in domestic investments in response to AJCA is partially attributable to the DPAD provision of AJCA.

${ }^{24}$ Because the AJCA was structured as a one-time windfall, allowing companies to repatriate foreign profits accumulated over prior periods one time, we are unable to directly examine the impact the Act had on the relation between corporate profit growth and economic growth.

${ }^{25}$ In addition to examining the effect of the AJCA on one-quarter-ahead economic activity, we also investigate the effect on two-quarters-ahead and three-quarters-ahead economic activity. We find that the AJCA is positively associated with two-quarters-ahead and three-quarters-ahead economic activity.
} 
other hand, the corporate tax rate in the United Kingdom has been much lower than that in the United States during a similar period and has very closely followed the decline in the rate of the other OECD countries.

Further, both Japan and the United Kingdom have recently changed their treatment of the foreign earnings of domestic companies. In 2009 (2010), Japan (the United Kingdom) moved from a worldwide taxation system — the system used in the United States, where repatriated foreign profits are taxed at the domestic rate less taxes paid abroad - to a territorial system, where taxes are paid only in the country in which the earnings are generated, eliminating the incremental domestic tax upon repatriation of foreign earnings. Therefore, if the higher tax rate in the United States and its worldwide taxation system have contributed to the growing disconnect between corporate profits and economic growth, we expect that we should not observe such a disconnect in the United Kingdom, regardless of the tax treatment of foreign earnings. In Japan, on the other hand, we expect the relation between corporate profit growth and economic growth to be similar to that in the United States, but we expect the disconnect in this relation to shrink after 2009 when Japan moved to a territorial tax regime. ${ }^{26}$

Table 6 reports the results of the comparison of the relation between corporate profits and economic growth in the United States and those in Japan and the United Kingdom. GDP and investment data for Japan are downloaded from the Cabinet Office of the Government of Japan. Japanese aggregate corporate profits data are retrieved from Nikkei America Inc. The data are available on a quarterly basis from 1994 to 2013. GDP, corporate profits, and investment data for

\footnotetext{
${ }^{26}$ After the shift to a territorial tax regime, Japan made additional changes to its corporate tax laws that should discourage the shifting of corporate profits to other countries. In 2010, Japan reformed its laws on tax havens, requiring that passive income of foreign affiliates in tax havens be taxed domestically. In 2012, the country began denying deductions for interest paid to related parties when those interest costs exceeded $50 \%$ of total income. While it is not possible to separate the magnitude of these new rules from that of the shift to a territorial regime, the changes are consistent with the goal of the shift to a territorial system and should therefore strengthen our expected results.
} 
the U.K. are downloaded from the British Office of National Statistics. The U.K. analysis is restricted to the years 1997 to 2013 because the necessary quarterly U.K. data only become available from 1997 onwards. All other data on Japan and the U.K. are downloaded from IHS Global Insights and the OECD website. See the Appendix for details.

Consistent with our conjectures, in Japan, where tax rates are relatively higher than the OECD average, growth in corporate profits is significantly higher than growth in the overall economy. Specifically, from 1994 to 2009, when Japan had a worldwide tax system, the tax rate was, on average, more than $11 \%$ higher than the average OECD rate. During this period, as shown in univariate analysis in Panel A of Table 6, investment and GDP grew at less than $0.2 \%$ per quarter, while corporate profits grew at $8.5 \%$ per quarter. After shifting to a territorial tax system (2010-2013), average growth in investments increased significantly to $0.80 \%$ (in comparison, average growth in investments is $0.15 \%$ during the worldwide tax system period). Further, we observe a marginal reduction in the disconnect between growth in corporate profits and GDP growth after the country moved to a territorial tax system. Panel B of Table 6 provides further evidence of this shift using multivariate tests. ${ }^{27}$ Columns 1 and 2 show that more corporate profits translate into subsequent investment after Japan shifts to a territorial tax system, while this relation was not significant under a worldwide tax system. The evidence suggests that tax rates affect companies' decisions to invest domestically and that the tax treatment of foreign earnings impacts the relation between corporate profit growth and economic growth.

In contrast, we do not observe higher corporate profit growth relative to economic growth in the United Kingdom, where the tax rate is comparable to the average OECD tax rate.

\footnotetext{
${ }^{27}$ The control variables used in these tests are similar, but not identical, to those used in the U.S. tests because the macroeconomic data for Japan and the United Kingdom are more limited than they are for the United States. In all tests, we attempt to mimic the U.S. data as closely as possible.
} 
Specifically, as shown in Panel A of Table 6, between 1997 and 2010, the U.K. tax rate was, on average, $29.62 \%$, about $0.4 \%$ below the average tax rate of the OECD countries. During this period, the U.K. economy grew, on average, at about $1.10 \%$ each quarter and corporate profits experienced quarterly growth of $0.77 \%$. After the move to a territorial tax system in 2011 , average domestic investment growth (1.61\%) increased significantly compared to the worldwide tax system period (1997-2010). However, as shown in Columns 3 and 4 of Panel B, Table 6, increases in domestic investment are not attributable to how corporate profits translate into subsequent domestic investment. Since the U.K. tax rate is comparable to the OECD average rate during the entire period sample period, the shift to a territorial tax system should not affect the relation between corporate profits and subsequent domestic investments. ${ }^{28}$

Overall, the evidence is consistent with our conjecture that relatively higher tax rates, as well as the tax treatment of foreign profits, contribute to the disconnect between the growth in corporate profits and the growth in the overall economy.

\subsection{Growth in financial assets of "mobile" industries}

Firms in "mobile" industries (e.g., pharmaceutical and high-tech industries) have large amounts of intellectual property and produce goods that are used around the world. Therefore, they are better suited to take advantage of the differences in tax rates across jurisdictions. Firms in these industries can use strategic transfer pricing, shift actual assets, and take advantage of global R\&D tax incentives, among other strategies, to move profits to low-tax countries, thereby reducing their tax burden (De Simone and Stomberg 2013). Kleinbard (2012) notes that mobile firms are able to increase their after-tax returns by deflecting income from high-tax countries to jurisdictions with

\footnotetext{
${ }^{28}$ While the U.K. tax rate was marginally below the average OECD rate, it was not below the rates of all OECD countries, providing U.K. companies with the incentive to shift and keep profits in certain low-tax countries.
} 
low taxes, without significant incremental risk. However, mobile firms cannot repatriate these profits to the United States without incurring an increased tax bill. Further, limits on their abilities to distribute earnings to shareholders through dividends and buybacks leads to higher holdings of cash and marketable securities. ${ }^{29}$ Firms with high levels of cash trapped abroad have limited investment opportunities (Edwards et al. 2015). Therefore, we expect that U.S. mobile industries' financial asset holdings (i.e., cash and marketable securities) will increase more than other industries as the OECD tax rate falls since firms in these industries seek profits abroad that remain abroad to avoid repatriation taxes.

Following De Simone and Stomberg (2013), we classify the SIC three-digit industries 283, 357, 367, 737, and 738 as mobile. Barth, Beaver, Hand, and Landsman (1999) classify these industries as "pharmaceuticals" (283), "computers" (357, 367, and 737), and "services" (738). The pharmaceutical and computer industries were responsible for half of all repatriated funds during the AJCA tax holiday (U.S. Senate, 2011), further supporting their classification as mobile.

Table 7 provides the results of our test of whether mobile industries increase their financial asset holdings at a rate greater than the rest of the corporate sector when the U.S. tax rate increases relative to the average OECD tax rate. We compare quarterly aggregate financial asset holdings of firms in the mobile industries to firms in other industries in quarters when the tax rate difference between the United States and OECD countries is above and below the time-series median. Aggregate financial asset holdings are measured as cash and short-term marketable securities scaled by total assets. All variables are downloaded from the Compustat quarterly file. ${ }^{30}$

\footnotetext{
${ }^{29}$ Several studies (e.g., Foley et al. 2007; Blouin et al. 2014) find evidence on the firm level that multinational companies hold large amounts of their unrepatriated foreign earnings in cash.

${ }^{30}$ We exclude financial firms (SIC codes 6,000-6,999) from our analyses as financial asset holdings can be an important part of these firms' operating assets and are influenced by regulation.
} 
Financial asset holdings for mobile industries increase much more than those in other industries in quarters when the U.S. tax rate increases relative to the OECD rate. Specifically, financial assets as a percentage of total assets for mobile industries increase by $77 \%$ from $13 \%$ to $23 \%$ when the tax rate difference is above the median versus when it is below the median. This increase is economically and statistically significant (t-statistic of the difference is 14.73). For nonmobile industries, while the increase in financial assets as a percentage of total assets (from $6 \%$ to $7 \%$ ) is also statistically significant (t-statistic of the difference is 6.19 ), the economic magnitude of the increase compared to that the mobile industries is much smaller. The increase in financial assets of other industries is only $1 \%$. Importantly, the difference-in-difference for the increases of financial holdings of mobile industries and other industries between the two sub-periods is economically and statistically significant (100\% with a t-statistic of 15.94$)$.

In conclusion, the evidence in Table 7 suggests that U.S. firms in industries that are able to take advantage of tax rate differences across jurisdictions (i.e., firms in mobile industries) increase their holdings of financial assets at a higher rate than other firms when the OECD tax rate is lower relative to the U.S. tax rate. The evidence is consistent with the conjecture that firms are holding more financial assets instead of repatriating profits (thereby avoiding repatriation taxes) and making fewer investments in the United States when the OECD tax rate is lower than the U.S. tax rate.

\section{Conclusion}

Our study systematically investigates the relation between growth in corporate profits and overall economic growth. We document that the relation between the growth in corporate profits and the growth in the economy in the United States depends on the U.S. corporate income tax rate relative to the average rate of all other OECD countries. We find that when the U.S. tax rate 
increase in relation to the average OECD rate, the difference between the growth in corporate profits and the overall economy also increases.

The underlying mechanism contributing to the disconnect between the growth in corporate profits and the overall economy is fewer corporate profits translating into subsequent domestic investments. We find that the relatively higher U.S. tax rate and the tax treatment of foreign earnings discourage U.S. firms from investing their earnings domestically and repatriating their foreign earnings to the United States. Relatedly, President Donald Trump has recently proposed reducing the U.S. corporate income tax rate and enact a deemed repatriation of currently deferred foreign earnings of U.S. multinationals at a tax rate of $10 \%$ (Cole 2016). Our results provide evidence of potential issues with the current system of taxation and suggest that a reduction in the U.S. tax rate and the move to a territorial tax system from a worldwide system can better align economic growth with growth in corporate profits by encouraging firms to invest domestically and repatriate foreign earnings.

In addition to the time-series analysis to identify these underlying channels, we exploit the tax shock of the American Jobs Creation Act of 2004, which provided a temporary tax reduction for repatriating foreign earnings and a deduction for domestically manufactured products, to identify the causal effect of the relatively higher U.S. tax costs on aggregate domestic investments, personal consumption, repatriations, and overall economic growth. The evidence suggests that aggregate investments, personal consumption, and repatriations increased significantly during the years when the AJCA reduced the tax cost of repatriating foreign earnings, and economic growth was higher in subsequent quarters. Finally, we also conduct cross-sectional and cross-country analyses to examine the impact of taxes on the relation between corporate profits and economic growth. 


\section{References}

Agell, J.., Lindh, T., Ohlsson, H., 1997. Growth and the public sector: A critical review essay. European Journal of Political Economy 13(1), 33-52.

Altshuler, R., Grubert, H., Newlon, T.S., 2000. Has U.S. investment abroad become more sensitive to tax rates? In International Taxation and Multinational Activity, edited by J. Hines Jr., Chicago: University of Chicago Press, 9-38.

Arif, S., Lee, C., 2014. Aggregate investment and investor sentiment. Review of Financial Studies, 27(11), 3241-3279.

Arnold, J., Brys, B., Heady, C., Johansson, A., Schwellnus, C., Vartia. L., 2011. Tax policy for economic recovery and growth. Economic Journal 121, 59-80.

Barth, M., Beaver, W., Hand, J., Landsman, W., 1999. Accruals, cash flows, and equity values. Review of Accounting Studies 3, 205-229.

Blanchard, O. J., Perotti, R.,2002. An empirical characterization of the dynamic effects of changes in government spending and taxes on output. Quarterly Journal of Economics 117(4), 1329-1368.

Blouin, J., Krull, L., 2009. Bringing it home: A study of the incentives surrounding the repatriation of foreign earnings under the American Jobs Creation Act of 2004. Journal of Accounting Research 47(4), 1027-1059.

Blouin, J., Krull, L., Robinson, L., 2012. Is U.S. multinational dividend repatriation policy influenced by reporting incentives? The Accounting Review 87(5), 1463-1491.

Blouin, J., Krull, L., Robinson, L., 2014. The location, composition, and investment implications of permanently reinvested earnings. Working paper.

Blouin, J., Krull, L., Schwab, C. 2014. The effect of the domestic production activities deduction on corporate payout behavior. Working Paper.

Boudoukh, J., Michaely, R., Richardson, M. P., Roberts, M. R., 2007. On the importance of measuring payout yield: implications for empirical asset pricing. Journal of Finance 62, 877915.

Bureau of Economic Analysis, 2014. Concepts and methods of the U.S. national income and product accounts. Available at www.bea.gov/national/pdf/all-chapters.pdf.

Cole, A. 2016. Details and analysis of Donald Trump's tax plan, September 2016. Tax Foundation: https://taxfoundation.org/details-analysis-donald-trump-tax-plan-2016/ 
De Mooij, R., Ederveen, S., 2003. Taxation and foreign direct investment: A synthesis of empirical research. International Tax and Public Finance 10, 673-693.

De Simone, L., Stomberg, B., 2013. Do investors differentially value tax avoidance by income mobile firms? Working Paper.

Dharmapala, D., Foley, F., Forbes, K., 2011. Watch what I do, not what I say: The unintended consequences of the Homeland Investment Act. Journal of Finance 66(3), 753-787.

Dyreng, S., Hanlon, M., Maydew, E., Thornock, J., 2014. Changes in corporate effective tax rates over the past twenty-five years. Working Paper.

Dyreng, S., Lindsay, B., 2009. Using financial accounting data to examine the effect of foreign operations located in tax havens and other countries on U.S. multinational firms' tax rates. Jounral of Accounting Research 47(5), 1283-1316.

Dyreng, S., Lindsey, B., Thornock, J., 2013. Exploring the role Delaware plays as a domestic tax haven. Journal of Financial Economics 108, 751-772.

The Economist. 2014. The fury of the makers. October 25.

Edwards, A., Kravet, T., Wilson, R., 2015. Trapped cash and the profitability of foreign acquisitions. Contemporary Accounting Research, forthcoming.

Faulkender, M., Petersen, M., 2012. Investment and Capital Constraints: Repatriations under the American Jobs Creation Act. The Review of Financial Studies 25, 3351-3388.

Foley, C., Hartzell, J., Titman, S., Twite, G., 2007. Why do firms hold so much cash? A taxbased explanation. Journal of Financial Economics 86, 579-607.

Giovannoni, O., Lu, L., Nguyen, D., Xu, A., 2014. What do we know about the labor share and the profit share? Part II: Empirical studies. Working Paper No. 804, Levy Economics Institute of Bard College.

Graham, J., Hanlon, M., Shevlin, T., 2010. Barriers to mobility: The lockout effect of U.S. taxation of worldwide corporate profits. National Tax Journal, 63(4), 1111-1144.

Graham, J., Hanlon, M., Shevlin, T., 2011. Real effects of accounting rules: Evidence from multinational firms' investment location and profit repatriation decisions. Journal of Accounting Research 49(1), 137-185.

Greenwood, J., Hercowitz, Z., Krussel, P., 1997. Long-run implications of investment-specific technological change. The American Economic Review 87(3), 342-362.

Gropp, R., Kostial, K. 2000. The disappearing tax base: Is foreign direct investment (FDI) eroding corporate income taxes? IMF Working Paper WP/00/173. 
Grubert, H., Mutti, J., 1991. Taxes, tariffs and transfer pricing in multinational corporate decision making. The Review of Economics and Statistics 73(2), 285-293.

Guscina, A., 2006. Effects of globalization on labor's share of income. IMF Working Paper.

Hall, R., Jorgenson, D., 1967. Tax policy and investment behavior. The American Economic Review 57(3), 391-414.

Hanlon, M., Heitzman, S., 2010. A review of tax research. Journal of Accounting and Economics $50,127-178$.

Hanlon, M., Lester, R., Verdi, R., 2015. The effect of repatriation tax costs on U.S. multinational investment. Journal of Financial Economics 116(1), 179-196.

Hartman, D., 1985. Tax policy and foreign direct investment. Journal of Public Economics 26, 107-121.

Hassett, K., Hubbard, R. G., 2002. Tax policy and business investment. In Handbook of Public Economics, volume 3, edited by A.J. Auerbach and M. Feldstein, Elseview, 1293-1343.

Hassett, K., Newmark, K., 2008. Taxation and business behavior: A review of recent literature. In Fundamental tax reform: Issues, choices and implications, edited by J.W. Diamond and G.R. Zodrow, Cambridge: MIT Press, 191-213.

Hines, J., 1997. Tax policy and the activities of multinational corporations. In Fiscal Policy: Lessons from Economic Research, edited by A.J. Auerbach, Cambridge: MIT Press, 401-445.

Hines, J., 1998. 'Tax sparing' and direct investment in developing countries. NBER Working Paper 6728.

Huang, C. C., Frentz, N., 2014. What really is the evidence on taxes and growth? A reply to the Tax Foundation. Center on Budget and Policy Priorities, Washington, D.C.

Klassen, K., Laplante, S., 2012. Are U.S. multinational corporations becoming more aggressive income shifters? Journal of Accounting Research 50(5), 1245-1286.

Klassen, K., Laplante, S., Carnaghan, C., 2014. A model of multinational income shifting and an application to tax planning with e-commerce. The Journal of the American Taxation Association $36(2), 27-53$.

Kleinbard, E. 2012. Stateless income's challenge to tax policy: Part 2. Tax Notes International, November 12, 2012: 671-687.

Krull, L., 2004. Permanently reinvested earnings, taxes, and earnings management. The Accounting Review 79(3), 745-767. 
Kothari, S.P., Lewellen, J., Warner, J., 2014. The Behavior of Aggregate Corporate Investment. Working Paper.

Krugman, P., 2008. Trade and wages, reconsidered. Brookings Papers on Economic Activity, 103-154.

Lester, R. Made in U.S.A? A study of firm responses to domestic production incentives. Working Paper.

Maydew, E., 2001. Empirical tax research in accounting: A discussion. Journal of Accounting and Economics 31, 389-403.

Mendoza, E., Milesi-Ferretti, G. M., Asea, P., 1991. On the ineffectiveness of tax policy in altering long-run growth: Harberger's super-neutrality conjecture. Journal of Public Economics 66(1), 99-126.

Mertens, K., Ravn, M., 2013. The dynamic effects of personal corporate income tax changes in the United States. American Economic Review 103(4), 121-1247.

Nessa, M., Shevlin, T., Wilson R., 2015. What do investors infer about future cash flows from foreign earnings for firms with low average foreign tax rates? Working Paper.

Norris, F., 2014. Corporate profits and wages slide. The New York Times. April 4.

Oler, M., Shevlin, T., Wilson, R., 2007. Examining investor expectations concerning tax savings on the repatriation of foreign earnings under the American Jobs Creation Act of 2004. Journal of the American Taxation Association 29(2), 25-55.

Ohrn, E. The business investment response to the Domestic Production Activities Deduction. University of Michigan Working Paper.

Poterba, J. 2000. Stock market wealth and consumption. Journal of Economic Perspectives 14 (2), 99-118.

Price Waterhouse \& Co., 1976. Corporate taxes in 80 countries. New York.

Price Waterhouse \& Co., 1978. Corporate taxes in 80 countries. New York.

Price Waterhouse \& Co., 1980. Corporate taxes in 80 countries. New York.

Redmiles, M., 2008. The one-time received dividend deduction. Internal Revenue Service Statistics of Income Bulletin 27, 102-114.

Romer, C., Romer, D., 2010. The macroeconomic effects of tax changes: estimates based on a new measure of fiscal shocks. The American Economic Review 100(3), 763-801. 
Shackelford, D., Shaviro, D., Slemrod, J., 2010. Taxation and the financial sector. In Taxation and the Financial Crisis, edited by J.S. Alworth and G. Arachi, Oxford: Oxford University Press, 148-173.

Shackelford, D., Slemrod, J., Sallee, J., 2011. Financial reporting, tax, and real decisions: toward a unifying framework. International Tax and Public Finance 18, 461-494.

Shackelford, D., Shevlin, T., 2001. Empirical tax research in accounting. Journal of Accounting and Economics 31, 321-387.

Shevlin, T., Shivakumar, L., Urcan, O., 2016. Macroeconomic effects of aggregate corporate tax avoidance: A cross-country analysis. Working Paper.

Slemrod, J., 1992. Do taxes matter? Lessons from the 1980's. The American Economic Review 82(2), 250-256.

U.S. Senate Permanent Subcommittee on Investigations, 2011. Repatriating Offshore Funds: 2004 Tax Windfall for Select Multinationals. October 11. 
Variable Appendix: Variable Descriptions by Country

Variable

$\underline{\text { United States }}$

$A C T$

$A T$

Comp

Con

$C P D$

$C P N$

Crisis

$D E F$

$F X$

$G D P$

\section{Definition}

An indicator equal to 1 for quarters Q4:2004 to Q4:2005, the period during which the American Jobs Creation Act allowed companies to repatriate foreign earnings at a lower tax rate

Quarterly aggregate total assets of U.S. companies, retrieved from Compustat

Quarter-over-quarter growth (in percent) in seasonally adjusted employee compensation, retrieved from the Bureau of Economic Analysis

Quarter-over-quarter growth (in percent) in seasonally adjusted personal consumption expenditures, retrieved from the Bureau of Economic Analysis

Quarter-over-quarter growth (in percent) in seasonally adjusted U.S. aggregate domestic corporate profits, which exclude foreign profits of U.S. companies and are adjusted for changes in the book value of inventory and capital, retrieved from the Bureau of Economic Analysis

Quarter-over-quarter growth (in percent) in seasonally adjusted U.S. aggregate national corporate profits, which include foreign profits of U.S. companies and are adjusted for changes in the book value of inventory and capital, retrieved from the Bureau of Economic Analysis

An indicator equal to 1 for quarters Q4:2007 to Q1:2009, and 0 otherwise

Quarterly default spread, defined as the difference between the yields on Aaa and Baa bonds, retrieved from the Federal Reserve Bank of St. Louis

The weighted average of the foreign exchange value of the U.S. dollar against a broad index of currencies that circulate widely, retrieved from FRED, Federal Reserve Bank of St. Louis

Quarter-over-quarter growth (in percent) in seasonally adjusted U.S. gross domestic product, retrieved from the Bureau of Economic Analysis 
GNP

Gov

Ineq

$I N V$

Inv_opp

Marketable Securities

(Short)

Openness

Productivity

Recession

REINV

REPAT

Ret

T-bill
Quarter-over-quarter growth (in percent) in seasonally adjusted U.S. gross national product, retrieved from the Bureau of Economic Analysis

Quarter-over-quarter growth (in percent) in seasonally adjusted government spending, retrieved from the Bureau of Economic Analysis

Percent of total income, including capital gains, earned by the wealthiest $1 \%$ of people in the United States, retrieved from The World Top Income Database

Quarter-over-quarter growth (in percent) in seasonally adjusted U.S. aggregate gross private domestic investment, retrieved from the Bureau of Economic Analysis. Private domestic investments includes three components: non-residential investment, residential investment, and change in inventories.

Quarter-over-quarter average growth (in percent) in GDP for all OECD countries, excluding the United States, retrieved from the OECD website

Quarterly aggregate cash holdings and short-term marketable securities of U.S. companies, retrieved from Compustat

The sum of quarterly imports and exports, scaled by quarterly GDP, retrieved from the Bureau of Economic Analysis

Quarterly output per hour for all non-farm businesses, retrieved from the Bureau of Labor Statistics

An indicator equal to 1 if the U.S. economy was in a recession during the quarter, as defined by the National Bureau of Economic Research, and 0 otherwise

Percentage of quarterly foreign earnings by U.S. firms that was reinvested abroad, retrieved from the Bureau of Economic Analysis

Percentage of quarterly foreign earnings by U.S. firms that was repatriated through dividends and withdrawals, retrieved from the Bureau of Economic Analysis

Quarterly value-weighted aggregate stock returns, retrieved from Kenneth French's website

Quarterly yield on the 10-year Treasury note, retrieved from CRSP 
Tax_diff

Tech

Term

$\underline{\text { Japan }}$

$C P D$

FX

GDP

$I N V$

Openness

Ret

T-bill

Tech

Term

Territorial
Difference between the U.S. corporate tax rate and the average tax rate of OECD countries in that quarter, retrieved from the OECD for years 19812013 and Corporate Taxes in 80 Countries for 1975-1980

Quarterly total investment scaled by quarterly GDP, retrieved from the Bureau of Economic Analysis

Quarterly difference between the returns on 10-year and 1-year Treasuries, retrieved from CRSP

Quarter-over-quarter growth (in percent) in Japanese aggregate corporate net operating surplus, retrieved from Nikkei America

Average quarterly Japanese-U.S. exchange rate (yen per dollar), retrieved from IHS Global Insights

Quarter-over-quarter growth (in percent) in seasonally adjusted Japanese gross domestic product, retrieved from the Cabinet Office of the Government of Japan

Quarter-over-quarter growth (in percent) in seasonally adjusted Japanese domestic investment, retrieved from the Cabinet Office of the Government of Japan

The sum of quarterly imports and exports, scaled by quarterly GDP, retrieved from the Cabinet Bureau of the Government of Japan and IHS Global Insights

Quarterly return on the Tokyo Stock Exchange All Shares Index, retrieved from the OECD

Quarterly yield on the 10-year Japanese government bond, retrieved from IHS Global Insights

Quarterly total investment scaled by quarterly GDP, retrieved from the Cabinet Bureau of the Government of Japan

Quarterly difference between the returns on 10-year and 2-year Japanese government bonds, retrieved from IHS Global Insights

Indicator equal to 1 when Japan taxes profits made abroad under a territorial tax system and 0 when profits are taxed under a worldwide system 


\section{$\underline{\text { United Kingdom }}$}

$C P$

$F X$

$G D P$

$I N V$

Openness

Ret

T-bill

Tech

Term

Territorial
Quarter-over-quarter growth (in percent) in U.K. aggregate corporate net operating surplus, retrieved from the Office for National Statistics

Average quarterly U.K.-U.S. exchange rate (pound per dollar), retrieved from IHS Global Insights

Quarter-over-quarter growth (in percent) in seasonally adjusted U.K. gross domestic product, retrieved from the Office for National Statistics

Quarter-over-quarter growth (in percent) in seasonally adjusted U.K. domestic investment, retrieved from the Office for National Statistics

The sum of quarterly imports and exports, scaled by quarterly GDP, retrieved from the Office for National Statistics and IHS Global Insights

Quarterly return on the FTSE 100 Index, retrieved from the OECD

Quarterly yield on the 10-year U.K. government bond, retrieved from IHS Global Insights

Quarterly total investment scaled by quarterly GDP, retrieved from the Office for National Statistics

Quarterly difference between the returns on 10-year and 2-year U.K. government bonds, retrieved from IHS Global Insights

Indicator equal to 1 when the U.K. taxes profits made abroad under a territorial tax system and 0 when profits are taxed under a worldwide system 


\section{Figure 1: Corporate Income Taxes Over Time}

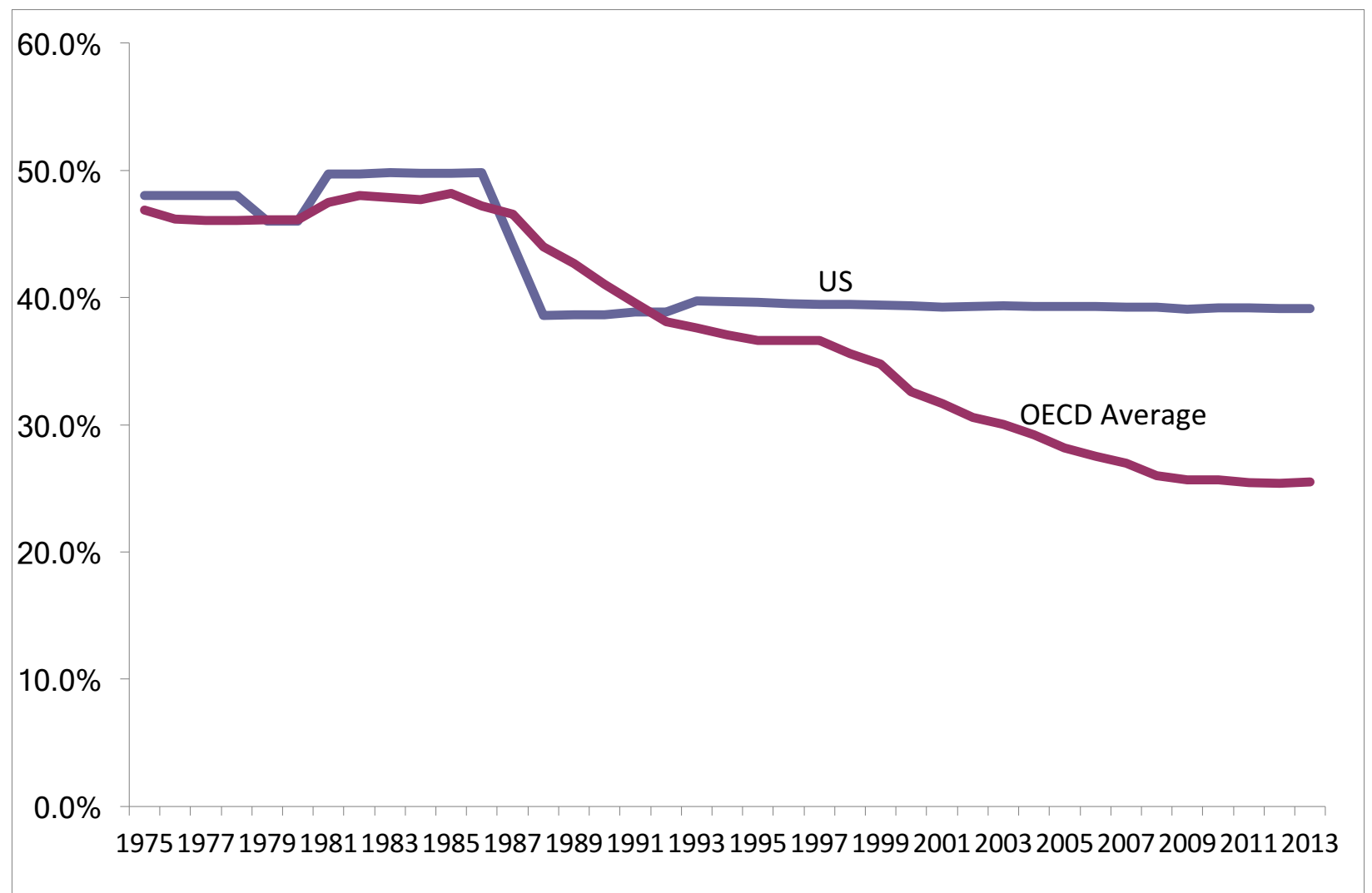

Figure 1 plots the corporate tax rate of the United States and the average corporate tax rate for all other OECD countries. 
Figure 2: Percent Foreign Corporate Profits Repatriated Over Time

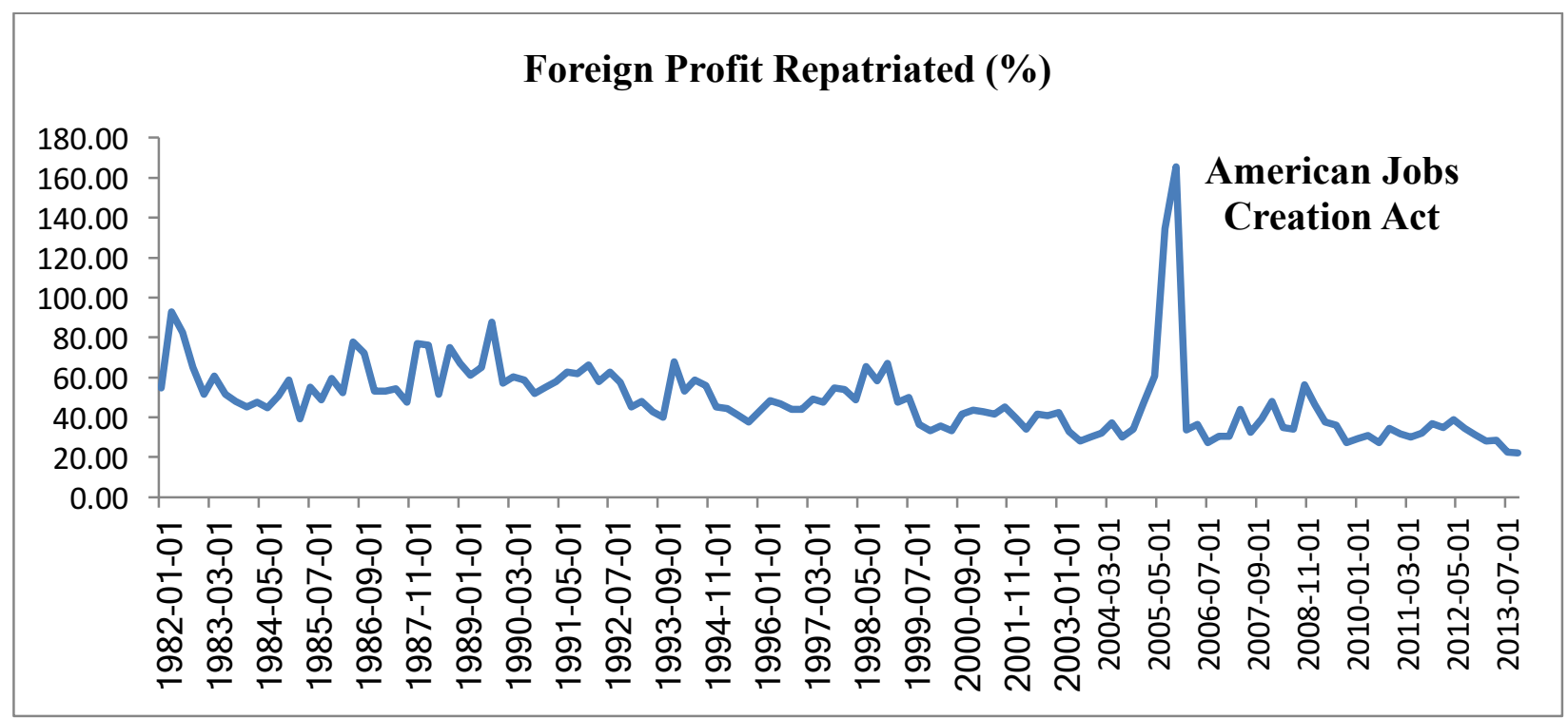

Figure 2 plots the percent of profits made abroad by U.S. companies that were repatriated to the United States and identifies a spike in repatriations during the years of the American Jobs Creation Act. Data on repatriations are available only from 1982. 


\section{Table 1: Descriptive Statistics}

Table 1 presents descriptive statistics for all variables of interest. Panel A presents descriptive statistics for the full sample of 155 observations, the period during which the difference between the U.S. corporate tax rate and the average OECD corporate tax rate is below median difference between the two rates $(2.60 \%)$, and the period in which the difference is above median. Variable definitions are in the Variable Appendix. Panel B presents the relation between tax changes, corporate profits, and economic growth components.

Panel A: Tax Differences and Economic Growth Components

\begin{tabular}{|c|c|c|c|c|c|c|c|}
\hline & Mean & Std Dev & 5 Perc & 25 Perc & Median & 75 Perc & 95 perc \\
\hline \multicolumn{8}{|c|}{ Full Sample (155 quarterly observations) } \\
\hline Tax_Diff $(* 100)$ & 4.70 & 5.46 & -4.00 & 1.61 & 2.60 & 10.08 & 13.72 \\
\hline GNP & 1.53 & 0.98 & 0.10 & 1.10 & 1.40 & 2.00 & 3.10 \\
\hline GDP & 1.54 & 0.98 & 0.20 & 1.10 & 1.40 & 2.00 & 3.20 \\
\hline CPD & 2.46 & 9.04 & -11.79 & -2.25 & 2.38 & 6.90 & 14.48 \\
\hline CPN & 2.28 & 6.21 & -7.62 & -0.89 & 2.98 & 5.69 & 11.11 \\
\hline INV & 1.55 & 4.00 & -5.30 & -0.40 & 1.50 & 3.90 & 8.20 \\
\hline REPAT & 49.07 & 18.99 & 28.57 & 36.06 & 46.83 & 57.52 & 76.97 \\
\hline REINV & 50.93 & 18.99 & 23.03 & 42.48 & 53.17 & 63.94 & 71.43 \\
\hline Gov & 1.59 & 1.13 & -0.14 & 0.89 & 1.50 & 2.20 & 3.77 \\
\hline Comp & 1.48 & 0.99 & -0.15 & 0.91 & 1.53 & 2.08 & 3.03 \\
\hline Con & 1.62 & 0.88 & 0.48 & 1.14 & 1.54 & 2.11 & 3.01 \\
\hline \multicolumn{8}{|c|}{ US Tax - OECD Tax: Below Median (76 quarters) } \\
\hline Tax_Diff $(* 100)$ & 0.35 & 2.28 & -5.41 & -0.71 & 1.61 & 1.99 & 2.59 \\
\hline GNP & 1.97 & 1.04 & 0.50 & 1.35 & 1.80 & 2.50 & 3.50 \\
\hline GDP & 1.97 & 1.03 & 0.30 & 1.30 & 1.80 & 2.60 & 3.60 \\
\hline CPD & 2.67 & 7.89 & -10.84 & -2.69 & 2.47 & 7.79 & 15.80 \\
\hline CPN & 2.47 & 5.83 & -7.62 & -1.13 & 3.12 & 6.54 & 11.43 \\
\hline INV & 1.98 & 5.83 & -7.62 & -1.13 & 3.12 & 6.54 & 11.43 \\
\hline REPAT & 58.57 & 4.61 & -6.40 & -0.40 & 1.90 & 4.55 & 10.10 \\
\hline REINV & 41.43 & 12.02 & 42.79 & 51.02 & 57.30 & 63.69 & 82.33 \\
\hline Gov & 2.06 & 12.02 & 17.67 & 36.31 & 42.71 & 48.98 & 57.21 \\
\hline Comp & 1.93 & 1.08 & 0.63 & 1.43 & 2.03 & 2.53 & 3.97 \\
\hline Con & 2.08 & 0.80 & 0.51 & 1.40 & 1.83 & 2.53 & 3.27 \\
\hline \multicolumn{8}{|c|}{ US Tax - OECD Tax: Above Median (79 quarters) } \\
\hline Tax_Diff $(* 100)$ & 8.88 & 4.23 & 2.60 & 3.83 & 9.27 & 13.28 & 13.73 \\
\hline GNP & 1.12 & 0.69 & -0.10 & 0.80 & 1.20 & 1.50 & 2.10 \\
\hline GDP & 1.13 & 0.73 & -0.20 & 0.90 & 1.20 & 1.50 & 2.20 \\
\hline CPD & 2.26 & 10.07 & -13.40 & -1.32 & 2.38 & 6.43 & 13.23 \\
\hline $\mathrm{CPN}$ & 2.11 & 6.59 & -8.50 & -0.77 & 2.83 & 4.99 & 11.10 \\
\hline INV & 1.15 & 3.30 & -4.90 & -0.40 & 1.40 & 3.40 & 5.20 \\
\hline REPAT & 43.30 & 20.15 & 27.31 & 32.73 & 39.03 & 47.59 & 66.85 \\
\hline REINV & 56.70 & 20.15 & 33.15 & 52.41 & 60.97 & 67.27 & 72.69 \\
\hline Gov & 1.14 & 0.99 & -0.38 & 0.53 & 1.11 & 1.61 & 2.69 \\
\hline Comp & 1.05 & 0.98 & -0.39 & 0.53 & 1.08 & 1.69 & 2.48 \\
\hline Con & 1.18 & 0.66 & 0.29 & 0.93 & 1.22 & 1.54 & 2.02 \\
\hline
\end{tabular}


Full Sample (155 quarterly observations): Other Controls

\begin{tabular}{lcccccccc} 
Term & 0.51 & 3.77 & -5.05 & -2.08 & -0.20 & 3.08 & 7.55 \\
DEF & 1.13 & 0.48 & 0.62 & 0.80 & 0.97 & 1.36 & 2.15 \\
T-bill & 1.58 & 1.38 & -0.02 & 0.73 & 1.43 & 2.19 & 3.91 \\
Ret & 3.25 & 8.56 & -12.84 & -1.19 & 4.01 & 8.97 & 16.02 \\
Recession & 0.14 & 0.34 & 0.00 & 0.00 & 0.00 & 0.00 & 1.00 \\
Openness & 0.22 & 0.04 & 0.16 & 0.18 & 0.20 & 0.24 & 0.30 \\
Tech & 17.64 & 1.84 & 14.16 & 16.41 & 17.82 & 19.11 & 20.21 \\
Productivity & 76.89 & 16.39 & 57.64 & 62.70 & 72.57 & 93.42 & 105.93 \\
FX & -0.14 & 3.10 & -5.25 & -2.80 & 0.06 & 1.90 & 5.07 \\
Inv_opp & 2.53 & 2.22 & -1.40 & 1.70 & 3.10 & 3.90 & 4.80 \\
Ineq & 15.74 & 4.41 & 8.87 & 11.99 & 15.49 & 19.75 & 22.83 \\
\hline
\end{tabular}

Panel B: Tax Differences, Corporate Profits, and Economic Growth Components

\begin{tabular}{|c|c|c|c|c|c|c|c|c|}
\hline \multirow[t]{2}{*}{ Dep Var } & \multicolumn{2}{|c|}{$\mathrm{INV}_{\mathrm{t}+1}$} & \multicolumn{2}{|c|}{$\mathrm{CONS}_{\mathrm{t}+1}$} & \multicolumn{2}{|c|}{$\mathrm{COMP}_{\mathrm{t}+1}$} & \multicolumn{2}{|c|}{$\mathrm{GOV}_{\mathrm{t}+1}$} \\
\hline & (1) & (2) & (3) & (4) & (5) & (6) & (7) & (8) \\
\hline Intercept & $\begin{array}{c}1.38 * * * \\
(3.72)\end{array}$ & $\begin{array}{c}1.57 * * * \\
(3.52)\end{array}$ & $\begin{array}{c}1.59 * * * \\
(8.85)\end{array}$ & $\begin{array}{c}1.94 * * * \\
(8.98)\end{array}$ & $\begin{array}{c}1.45^{* * *} \\
(7.05)\end{array}$ & $\begin{array}{c}1.85^{* * *} \\
(7.93)\end{array}$ & $\begin{array}{c}1.53 * * * \\
(7.31)\end{array}$ & $\begin{array}{c}1.83 * * * \\
(6.74)\end{array}$ \\
\hline $\mathrm{CPD}_{\mathrm{t}}$ & $\begin{array}{c}0.11 * * \\
(2.04)\end{array}$ & $\begin{array}{c}0.23 * * * \\
(3.61)\end{array}$ & $\begin{array}{c}0.01 \\
(0.86)\end{array}$ & $\begin{array}{c}0.01 \\
(1.39)\end{array}$ & $\begin{array}{c}0.01 \\
(1.48)\end{array}$ & $\begin{array}{c}0.01 \\
(0.99)\end{array}$ & $\begin{array}{c}0.01 \\
(1.08)\end{array}$ & $\begin{array}{c}0.01 \\
(0.42)\end{array}$ \\
\hline Tax_diff $f_{t}$ & & $\begin{array}{c}-5.98 \\
(-0.73)\end{array}$ & & $\begin{array}{c}-7.53 * * * \\
(-3.19)\end{array}$ & & $\begin{array}{c}-8.61 * * * \\
(-3.24)\end{array}$ & & $\begin{array}{c}-6.33 * * \\
(-2.12)\end{array}$ \\
\hline Tax_diff & $P_{t}$ & $\begin{array}{c}-1.70 * * * \\
(-2.97)\end{array}$ & & $\begin{array}{c}-0.10 \\
(-1.17)\end{array}$ & & $\begin{array}{c}0.05 \\
(0.53)\end{array}$ & & $\begin{array}{c}0.10 \\
(0.52)\end{array}$ \\
\hline Adj. $R^{2}$ & 0.06 & 0.13 & 0.00 & 0.23 & 0.01 & 0.22 & 0.00 & 0.08 \\
\hline Obs & 155 & 155 & 155 & 155 & 155 & 155 & 155 & 155 \\
\hline
\end{tabular}




\section{Table 2: Corporate Profits and Economic Growth}

Table 2 reports the results for regressions of corporate profit growth on quarter-ahead economic growth. In Panel A (B), economic growth is measure as the quarterly growth, in percent, in seasonally adjusted gross national (domestic) product, GNP (GDP), from quarter $t$ to $t+1$. Growth in corporate profits, CPN (CPD), is measured as the quarterly growth, in percent, in national (domestic) corporate profits. Tax_diff*CPN (Tax_diff*CPD) is the interaction between Tax_diff, the difference between the U.S. corporate tax rate and the average OECD corporate tax rate, and national (domestic) corporate profits. Variable definitions are provided in the Appendix. $t$-statistics with Newey-West correction for autocorrelation are reported in parentheses. $* * *$, and $* * *$ indicate significance at the $0.10,0.05$, and 0.01 levels, respectively.

Panel A: National corporate profits and quarter-ahead GNP

\begin{tabular}{|c|c|c|c|c|c|}
\hline \multirow[t]{2}{*}{ Dep Var } & \multicolumn{5}{|c|}{$\mathrm{GNP}_{\mathrm{t}+1}$} \\
\hline & (1) & (2) & (3) & (4) & (5) \\
\hline Intercept & $\begin{array}{c}1.48 * * * \\
(8.85)\end{array}$ & $\begin{array}{c}1.78 * * * \\
(8.74)\end{array}$ & $\begin{array}{c}1.76^{* * * *} \\
(8.98)\end{array}$ & $\begin{array}{c}1.18 * * * \\
(5.09)\end{array}$ & $\begin{array}{l}3.03^{*} \\
(1.89)\end{array}$ \\
\hline $\mathrm{CPN}_{\mathrm{t}}$ & $\begin{array}{l}0.03 * * \\
(2.09)\end{array}$ & $\begin{array}{c}0.05 * * * \\
(2.93)\end{array}$ & $\begin{array}{c}0.05 * * * \\
(2.88)\end{array}$ & $\begin{array}{c}0.03 * * \\
(2.19)\end{array}$ & $\begin{array}{l}0.03 * * \\
(2.29)\end{array}$ \\
\hline Tax_diff ${ }_{t}$ & & $\begin{array}{c}-6.67 * * * \\
(-2.94)\end{array}$ & $\begin{array}{c}-4.85 * * \\
(-2.60)\end{array}$ & $\begin{array}{c}-3.17 * * \\
(-2.00)\end{array}$ & $\begin{array}{c}5.28 \\
(1.48)\end{array}$ \\
\hline Tax_diff ${ }_{t} * C P N_{t}$ & & $\begin{array}{c}-0.31 * * \\
(-2.16)\end{array}$ & $\begin{array}{c}-0.35 * * \\
(-2.44)\end{array}$ & $\begin{array}{c}-0.22 * * \\
(-2.30)\end{array}$ & $\begin{array}{c}-0.19 * * \\
(-2.00)\end{array}$ \\
\hline Crisis & & & $\begin{array}{c}-1.59 * * * \\
(-8.26)\end{array}$ & $\begin{array}{c}-1.14 * * * \\
(-7.01)\end{array}$ & $\begin{array}{c}-0.73 * * * \\
(-3.61)\end{array}$ \\
\hline $\mathrm{GNP}_{\mathrm{t}}$ & & & & $\begin{array}{c}0.34 * * * \\
(4.15)\end{array}$ & $\begin{array}{c}0.02 \\
(0.15)\end{array}$ \\
\hline Term $_{t}$ & & & & & $\begin{array}{c}-0.70 \\
(-0.48)\end{array}$ \\
\hline $\mathrm{DEF}_{\mathrm{t}}$ & & & & & $\begin{array}{c}6.59 \\
(0.33)\end{array}$ \\
\hline T-bill $t_{t}$ & & & & & $\begin{array}{c}5.34 \\
(1.10)\end{array}$ \\
\hline $\operatorname{Ret}_{t}$ & & & & & $\begin{array}{c}0.88 \\
(1.07)\end{array}$ \\
\hline Recession $_{\mathrm{t}}$ & & & & & $\begin{array}{c}-1.03 * * * \\
(-2.74)\end{array}$ \\
\hline openness $_{t}$ & & & & & $\begin{array}{c}1.57 \\
(0.32)\end{array}$ \\
\hline $\mathrm{Tech}_{\mathrm{t}}$ & & & & & $\begin{array}{c}0.04 \\
(0.80)\end{array}$ \\
\hline Productivity $_{t}$ & & & & & $\begin{array}{l}-0.02 \\
(-0.79)\end{array}$ \\
\hline $\mathrm{FX}_{\mathrm{t}}$ & & & & & $\begin{array}{l}-0.01 \\
(-0.51)\end{array}$ \\
\hline Inv_opp $p_{t}$ & & & & & $\begin{array}{l}0.04 * * \\
(2.14)\end{array}$ \\
\hline Ineq $_{t}$ & & & & & $\begin{array}{c}-0.10 * * * \\
(-2.72)\end{array}$ \\
\hline Adj. $R^{2}$ & 0.03 & 0.20 & 0.28 & 0.36 & 0.48 \\
\hline Obs & 155 & 155 & 155 & 155 & 155 \\
\hline
\end{tabular}


Table 2. Continued.

Panel B: Domestic corporate profits and quarter-ahead GDP

\begin{tabular}{|c|c|c|c|c|c|}
\hline \multirow[t]{2}{*}{ Dep Var } & \multicolumn{5}{|c|}{$\mathrm{GDP}_{\mathrm{t}+1}$} \\
\hline & (1) & (2) & (3) & (4) & (5) \\
\hline Intercept & $\begin{array}{c}1.49 * * * \\
(8.52)\end{array}$ & $\begin{array}{c}1.80 * * * \\
(8.47)\end{array}$ & $\begin{array}{c}1.78 * * * \\
(8.67)\end{array}$ & $\begin{array}{c}1.19 * * * \\
(4.98)\end{array}$ & $\begin{array}{l}3.33 * * \\
(2.08)\end{array}$ \\
\hline $\mathrm{CPD}_{\mathrm{t}}$ & $\begin{array}{c}0.02 \\
(1.64)\end{array}$ & $\begin{array}{c}0.04 * * * \\
(3.16)\end{array}$ & $\begin{array}{c}0.04 * * * \\
(3.07)\end{array}$ & $\begin{array}{l}0.02 * * \\
(2.25)\end{array}$ & $\begin{array}{l}0.02 * * \\
(2.40)\end{array}$ \\
\hline Tax_diff & & $\begin{array}{c}-6.96 * * * \\
(-2.97)\end{array}$ & $\begin{array}{c}-5.37 * * * \\
(-2.75)\end{array}$ & $\begin{array}{l}-3.59^{* *} \\
(-2.19)\end{array}$ & $\begin{array}{c}5.63 \\
(1.61)\end{array}$ \\
\hline Tax_diff $f_{t} * C P D_{t}$ & & $\begin{array}{c}-0.30 * * * \\
(-2.78)\end{array}$ & $\begin{array}{c}-0.29 * * * \\
(-2.76)\end{array}$ & $\begin{array}{l}-0.17 * * \\
(-2.05)\end{array}$ & $\begin{array}{c}-0.16 * * \\
(-2.18)\end{array}$ \\
\hline Crisis & & & $\begin{array}{c}-1.45 * * * \\
(-7.69)\end{array}$ & $\begin{array}{c}-1.02 * * * \\
(-6.83)\end{array}$ & $\begin{array}{c}-0.63 * * * \\
(-3.45)\end{array}$ \\
\hline $\mathrm{GDP}_{\mathrm{t}}$ & & & & $\begin{array}{c}0.34 * * * \\
(4.26)\end{array}$ & $\begin{array}{c}0.01 \\
(0.10)\end{array}$ \\
\hline Term $_{t}$ & & & & & $\begin{array}{c}-0.81 \\
(-0.57)\end{array}$ \\
\hline $\mathrm{DEF}_{\mathrm{t}}$ & & & & & $\begin{array}{c}2.69 \\
(0.14)\end{array}$ \\
\hline T-bill $t_{t}$ & & & & & $\begin{array}{c}6.39 \\
(1.16)\end{array}$ \\
\hline $\operatorname{Ret}_{t}$ & & & & & $\begin{array}{c}0.57 \\
(0.82)\end{array}$ \\
\hline Recession $_{t}$ & & & & & $\begin{array}{c}-1.05 * * * \\
(-2.82)\end{array}$ \\
\hline openness $_{t}$ & & & & & $\begin{array}{c}2.32 \\
(0.46)\end{array}$ \\
\hline $\operatorname{Tech}_{t}$ & & & & & $\begin{array}{c}0.03 \\
(0.67)\end{array}$ \\
\hline Productivity $_{t}$ & & & & & $\begin{array}{c}-0.02 \\
(-1.17)\end{array}$ \\
\hline $\mathrm{FX}_{\mathrm{t}}$ & & & & & $\begin{array}{c}-0.01 \\
(-0.49)\end{array}$ \\
\hline Inv_opp $p_{t}$ & & & & & $\begin{array}{c}0.04 * * \\
(2.41)\end{array}$ \\
\hline Ineq $_{t}$ & & & & & $\begin{array}{c}-0.09 * * \\
(-2.29)\end{array}$ \\
\hline Adj. $R^{2}$ & 0.02 & 0.22 & 0.29 & 0.37 & 0.49 \\
\hline Obs & 155 & 155 & 155 & 155 & 155 \\
\hline
\end{tabular}




\section{Table 3: Corporate Profits and Quarter-Ahead Investments}

Table 3 presents the results for regressions of corporate profit growth on quarter-ahead growth, in percent, in domestic investment. Growth in investment (INV) is measured as the quarterly growth, in percent, in seasonally adjusted gross private domestic investment from quarter $t$ to $t+1$. Growth in corporate profits (CPD) is measured as the quarterly growth, in percent, in domestic corporate profits from quarter $\mathrm{t}-1$ to $\mathrm{t}$. Variable definitions are provided in the Appendix. $t$-statistics with Newey-West correction for autocorrelation are reported in parentheses. *, **, and *** indicate significance at the $0.10,0.05$, and 0.01 levels, respectively.

$\mathrm{INV}_{\mathrm{t}+1}=\alpha+\delta_{1} \mathrm{CPD}_{\mathrm{t}}+\delta_{2}$ Tax $\operatorname{diff}_{\mathrm{t}}+\delta_{3}$ Tax $\operatorname{diff}_{\mathrm{t}} * \mathrm{CPD}_{\mathrm{t}}+\delta_{4}$ Crisis $_{\mathrm{t}}+\delta_{5} \mathrm{INV}_{\mathrm{t}}+\delta_{6} \mathrm{GDP}_{\mathrm{t}}+\delta_{7} \mathrm{Term}_{\mathrm{t}}+\delta_{8} \mathrm{DEF}_{\mathrm{t}}+\delta_{9} \mathrm{~T}_{-\mathrm{note}_{\mathrm{t}}}$ $+\delta_{10}$ Ret $_{\mathrm{t}}+\delta_{11}$ Recession $\delta_{11}$ Openness $_{\mathrm{t}}+\delta_{12} \mathrm{Tech}_{\mathrm{t}}+\delta_{13}$ Productivity $_{\mathrm{t}}+\delta_{14} \mathrm{FX}_{\mathrm{t}}+\delta_{15}$ Inv_opp $_{\mathrm{t}}+\delta_{16}$ Ineq $_{\mathrm{t}}+\varepsilon_{\mathrm{t}+1}$

\begin{tabular}{|c|c|c|c|c|c|}
\hline \multirow[t]{2}{*}{ Dep Var } & \multicolumn{5}{|c|}{$\mathrm{INV}_{\mathrm{t}+1}$} \\
\hline & (1) & (2) & (3) & (4) & (5) \\
\hline Intercept & $1.38^{* * *}$ & $1.57 * * *$ & $1.48^{* * *}$ & $1.18^{* * *}$ & $26.77 * * *$ \\
\hline & $(3.72)$ & $(3.52)$ & $(3.77)$ & $(3.74)$ & $(5.34)$ \\
\hline $\mathrm{CPD}_{\mathrm{t}}$ & $0.11 * *$ & $0.23 * * *$ & $0.23 * * *$ & $0.21 * * *$ & $0.11 * * *$ \\
\hline & (2.04) & $(3.61)$ & $(3.53)$ & $(3.82)$ & $(2.68)$ \\
\hline Tax_diff ${ }_{t}$ & & -5.98 & 2.13 & 1.77 & $42.69 * * *$ \\
\hline & & $(-0.73)$ & $(0.47)$ & $(0.45)$ & $(4.44)$ \\
\hline Tax $\operatorname{diff}_{t} *$ CPDt & & $-1.70 * * *$ & $-1.67 * * *$ & $-1.47 * * *$ & $-0.74 * *$ \\
\hline & & $(-2.97)$ & $(-3.07)$ & $(-3.05)$ & $(-2.30)$ \\
\hline Crisis & & & $-7.43 * * *$ & $-6.18 * * *$ & $-2.58 * * *$ \\
\hline & & & $(-6.34)$ & $(-5.62)$ & $(-3.45)$ \\
\hline $\operatorname{Inv}_{t}$ & & & & $0.19 * * *$ & $-0.28 * * *$ \\
\hline & & & & (2.69) & $(-2.86)$ \\
\hline $\mathrm{GDP}_{\mathrm{t}}$ & & & & & $\begin{array}{l}1.48 * * \\
(2.53)\end{array}$ \\
\hline Term $_{t}$ & & & & & $\begin{array}{l}-9.32 \\
(-141)\end{array}$ \\
\hline $\mathrm{DEF}_{\mathrm{t}}$ & & & & & $\begin{array}{c}-183.06^{* *} \\
(-2.52)\end{array}$ \\
\hline T-bill $t_{t}$ & & & & & $\begin{array}{c}59.25^{* * *} \\
(2.90)\end{array}$ \\
\hline $\operatorname{Ret}_{t}$ & & & & & $\begin{array}{l}-2.10 \\
(-0.73)\end{array}$ \\
\hline Recession $_{t}$ & & & & & $\begin{array}{c}-4.43 * * * \\
(-3.32)\end{array}$ \\
\hline openness $_{t}$ & & & & & $\begin{array}{l}-22.17 \\
(-0.98)\end{array}$ \\
\hline $\mathrm{Tech}_{\mathrm{t}}$ & & & & & $\begin{array}{c}-0.90 * * * \\
(-4.70)\end{array}$ \\
\hline Productivity $_{t}$ & & & & & $\begin{array}{l}-0.10 \\
(-1.03)\end{array}$ \\
\hline $\mathrm{FX}_{\mathrm{t}}$ & & & & & $\begin{array}{c}0.10 \\
(1.51)\end{array}$ \\
\hline Inv_opp $p_{t}$ & & & & & $\begin{array}{c}0.11 \\
(1.21)\end{array}$ \\
\hline Ineq $_{t}$ & & & & & $\begin{array}{c}0.03 \\
(0.20)\end{array}$ \\
\hline Adj. $R^{2}$ & 0.06 & 0.13 & 0.25 & 0.28 & 0.50 \\
\hline Obs & 155 & 155 & 155 & 155 & 155 \\
\hline
\end{tabular}




\section{Table 4: Repatriation of Corporate Profits}

Table 4 presents the results of the effect of relative U.S. tax rates on the percentage of quarterly foreign profits earned by U.S. companies that are repatriated. Percentage of foreign profits repatriated (REPAT) is for quarter $\mathrm{t}+1$. Data on repatriations are available only from 1982, hence the analysis period is 1982-2013. Growth in corporate profits (CPN) is measured as the quarterly growth, in percent, in national corporate profits from quarter t- 1 to t. See the Variable Appendix for variable descriptions. $t$-statistics with Newey-West correction for autocorrelation are reported in parentheses. $*, * *$, and $* * *$ indicate significance at the $0.10,0.05$, and 0.01 levels, respectively.

\begin{tabular}{|c|c|c|c|c|c|}
\hline \multirow[t]{2}{*}{ Dep Var } & \multicolumn{5}{|c|}{$\%$ Repatriation ${ }_{t+1}$} \\
\hline & (1) & (2) & (3) & (4) & (5) \\
\hline Intercept & $49.42 * * *$ & $57.58 * * *$ & $57.64 * * *$ & $57.76^{* * * *}$ & $67.25^{* * *}$ \\
\hline $\mathrm{CPN}_{\mathrm{t}}$ & $\begin{array}{c}(14.56) \\
-0.28 * * \\
(-2.18)\end{array}$ & $\begin{array}{c}(41.38) \\
-0.26^{* *} \\
(-2.16)\end{array}$ & $\begin{array}{c}(42.79) \\
-0.24 * * \\
(-2.01)\end{array}$ & $\begin{array}{c}(12.63) \\
-0.24 * * \\
(-2.10)\end{array}$ & $\begin{array}{c}(2.63) \\
-0.16^{* *} \\
(-2.11)\end{array}$ \\
\hline Tax_diff $f_{t}$ & & $\begin{array}{c}-151.21 * * * * \\
(-5.00)\end{array}$ & $\begin{array}{c}-158.04 * * * \\
(-4.59)\end{array}$ & $\begin{array}{c}-158.32 * * * \\
(-3.84)\end{array}$ & $\begin{array}{c}-109.81 * * \\
(-2.50)\end{array}$ \\
\hline Crisis & & & $\begin{array}{c}6.16 \\
(1.30)\end{array}$ & $\begin{array}{c}6.06 \\
(1.51)\end{array}$ & $\begin{array}{c}0.44 \\
(0.07)\end{array}$ \\
\hline $\mathrm{GNP}_{\mathrm{t}}$ & & & & $\begin{array}{c}-0.08 \\
(-0.03)\end{array}$ & $\begin{array}{c}-0.05 \\
(-0.02)\end{array}$ \\
\hline Term $_{t}$ & & & & & $\begin{array}{c}97.37^{*} \\
(1.82)\end{array}$ \\
\hline $\mathrm{DEF}_{\mathrm{t}}$ & & & & & $\begin{array}{c}284.84 \\
(1.09)\end{array}$ \\
\hline T-bill ${ }_{t}$ & & & & & $\begin{array}{c}-216.48 \\
(-0.97)\end{array}$ \\
\hline $\operatorname{Ret}_{t}$ & & & & & $\begin{array}{l}-0.31 \\
(-0.03)\end{array}$ \\
\hline Recession $_{t}$ & & & & & $\begin{array}{c}6.94 \\
(0.94)\end{array}$ \\
\hline openness $_{t}$ & & & & & $\begin{array}{l}-91.14 \\
(-0.55)\end{array}$ \\
\hline Tech $_{t}$ & & & & & $\begin{array}{c}0.35 \\
(0.30)\end{array}$ \\
\hline Productivity $_{t}$ & & & & & $\begin{array}{c}-0.30 \\
(-0.57)\end{array}$ \\
\hline $\mathrm{FX}_{\mathrm{t}}$ & & & & & $\begin{array}{c}0.50 \\
(0.67)\end{array}$ \\
\hline Inv_opp $p_{t}$ & & & & & $\begin{array}{l}0.93 * * \\
(2.29)\end{array}$ \\
\hline Ineq $_{t}$ & & & & & $\begin{array}{c}1.34 \\
(1.02)\end{array}$ \\
\hline Adj. $R^{2}$ & 0.00 & 0.20 & 0.20 & 0.19 & 0.19 \\
\hline Obs & 128 & 128 & 128 & 128 & 128 \\
\hline
\end{tabular}




\section{Table 5: American Jobs Creation Act and Investments}

Table 5 examines the effect of the AJCA on repatriations of foreign profits by U.S. multinationals, domestic investments, domestic personal consumption expenditures, and economic growth. Percentage of foreign profits repatriated (PCT_Repatriation) is for quarter t. Growth in investment (INV) is measured as the quarterly growth, in percent, in seasonally adjusted gross private domestic investment from quarter $t$ to $t+1$. Growth in personal consumption (Con) is measured as the quarterly growth, in percent, in seasonally adjusted personal consumption expenditures from quarter $\mathrm{t}$ to $\mathrm{t}+1$. Economic growth (GDP (GNP)) is measured as the quarterly growth, in percent, in seasonally adjusted gross domestic product (gross national product) from quarter $t$ to $t+1$. ACT equals 1 for quarters Q4:2004 to Q4:2005, when U.S. multinational firms were allowed to repatriate foreign earnings at a lower tax rate. See the Variable Appendix for variable descriptions. t-statistics with Newey-West correction for autocorrelation are reported in parentheses. $* * *$, and $* * *$ indicate significance at the $0.10,0.05$, and 0.01 levels, respectively.

$\mathrm{DV}=\alpha+\tau_{1} \mathrm{ACT}+\tau_{2}$ Crisis $+\tau_{3}$ Term $_{\mathrm{t}}+\tau_{4} \mathrm{DEF}_{\mathrm{t}}+\tau_{5} \mathrm{~T}_{\text {-note }}+\tau_{6}$ Ret $_{\mathrm{t}}+\tau_{7}$ Recession $+\tau_{8}$ Openness $_{\mathrm{t}}+\tau_{9}$ Tech $_{\mathrm{t}}+$ $\tau_{10}$ Productivity $_{\mathrm{t}}+\tau_{11} \mathrm{FX}_{\mathrm{t}}+\tau_{12}$ Inv_opp $_{\mathrm{t}}+\tau_{13}$ Ineq $_{\mathrm{t}}+\tau_{14} \mathrm{CP}_{\mathrm{t}}+\tau_{15}$ Economic growth $_{\mathrm{t}}+\varepsilon_{\mathrm{t}}$

\begin{tabular}{|c|c|c|c|c|c|}
\hline \multirow[t]{2}{*}{ Dep Var } & PCT_Repatriation ${ }_{t}$ & $\mathrm{INV}_{\mathrm{t}+1}$ & $\operatorname{Con}_{\mathrm{t}+1}$ & $\mathrm{GDP}_{\mathrm{t}+1}$ & $\mathrm{GNP}_{\mathrm{t}+1}$ \\
\hline & (1) & (2) & (3) & (4) & (5) \\
\hline \multirow[t]{2}{*}{ Intercept } & $164.38 * * *$ & $10.72 *$ & 1.33 & 1.88 & 1.70 \\
\hline & (11.08) & (1.89) & (1.39) & (1.60) & (1.44) \\
\hline \multirow[t]{2}{*}{ Act } & $57.75 * * *$ & $1.96 * * *$ & $0.39 * *$ & $0.67 * * *$ & $0.64 * * *$ \\
\hline & (4.08) & (2.78) & (2.41) & (3.88) & (3.70) \\
\hline \multirow{2}{*}{ Crisis $_{t}$} & 1.64 & $-1.93 * *$ & $-0.85^{* * *}$ & $-0.50 * *$ & $-0.60 * *$ \\
\hline & $(0.41)$ & $(-2.26)$ & $(-3.22)$ & $(-2.24)$ & $(-2.55)$ \\
\hline \multirow[t]{2}{*}{ Term $_{t}$} & -41.23 & -9.75 & 0.10 & -1.29 & -1.17 \\
\hline & $(-1.40)$ & $(-1.32)$ & $(0.07)$ & $(-0.94)$ & $(-0.86)$ \\
\hline \multirow{2}{*}{$\mathrm{DEF}_{\mathrm{t}}$} & $697.72 * * *$ & -95.72 & $36.77 * *$ & 12.03 & 15.62 \\
\hline & $(3.11)$ & $(-1.33)$ & $(2.54)$ & $(0.67)$ & $(0.86)$ \\
\hline \multirow[t]{2}{*}{ T-bill $t_{t}$} & 194.11 & $84.54 * * *$ & -2.68 & 8.12 & 6.76 \\
\hline & $(1.08)$ & $(4.20)$ & $(-0.53)$ & (1.46) & (1.37) \\
\hline \multirow[t]{2}{*}{$\operatorname{Ret}_{t}$} & $-19.16^{* *}$ & 0.21 & $1.11^{* *}$ & 0.86 & 1.11 \\
\hline & $(-2.36)$ & $(0.07)$ & $(2.46)$ & $(1.27)$ & $(1.42)$ \\
\hline \multirow[t]{2}{*}{ Recession $_{t}$} & -3.21 & $-4.08 * * *$ & $-0.72 * *$ & $-1.08 * * *$ & $-1.06^{* * *}$ \\
\hline & $(-0.57)$ & $(-3.04)$ & $(-2.18)$ & $(-2.85)$ & $(-2.80)$ \\
\hline \multirow{2}{*}{ openness $_{t}$} & 26.57 & -16.32 & 2.79 & 3.66 & 2.83 \\
\hline & $(0.36)$ & $(-0.84)$ & $(0.82)$ & $(0.80)$ & $(0.66)$ \\
\hline \multirow{2}{*}{ Tech $_{t}$} & $-3.78 * * *$ & $-0.56^{* *}$ & $0.09 * *$ & 0.04 & 0.04 \\
\hline & $(-4.49)$ & $(-2.31)$ & $(2.16)$ & $(0.73)$ & $(0.85)$ \\
\hline \multirow[t]{2}{*}{ Productivity $_{t}$} & $-1.50 * * *$ & 0.09 & -0.01 & 0.00 & 0.00 \\
\hline & $(-6.07)$ & (1.36) & $(-0.95)$ & $(-0.17)$ & $(0.25)$ \\
\hline \multirow[t]{2}{*}{$\mathrm{FX}_{\mathrm{t}}$} & 0.14 & 0.09 & $-0.03 *$ & -0.01 & -0.01 \\
\hline & $(0.37)$ & $(1.45)$ & $(-1.87)$ & $(-0.43)$ & $(-0.51)$ \\
\hline \multirow[t]{2}{*}{ Inv_opp $p_{t}$} & $1.05 * * *$ & 0.05 & $0.03 *$ & $0.04 * *$ & $0.03 *$ \\
\hline & $(2.84)$ & $(0.46)$ & $(1.74)$ & $(2.11)$ & $(1.90)$ \\
\hline \multirow[t]{2}{*}{ Ineq $_{t}$} & $3.22 * * *$ & -0.22 & $-0.10 * *$ & $-0.13 * * *$ & $-0.13 * * *$ \\
\hline & $(3.20)$ & $(-1.51)$ & $(-2.05)$ & $(-2.85)$ & $(-3.17)$ \\
\hline \multirow[t]{2}{*}{$\mathrm{CPN}_{\mathrm{t}}$} & 0.10 & & & & 0.01 \\
\hline & $(0.52)$ & & & & $(1.54)$ \\
\hline \multirow[t]{2}{*}{$\mathrm{GNP}_{\mathrm{t}}$} & -2.57 & & & & 0.03 \\
\hline & $(-1.57)$ & & & & $(0.34)$ \\
\hline \multirow[t]{2}{*}{$\mathrm{CPD}_{\mathrm{t}}$} & & $0.06^{*}$ & 0.00 & $0.01 *$ & \\
\hline & & (1.78) & $(0.36)$ & (1.66) & \\
\hline \multirow[t]{2}{*}{$\mathrm{GDP}_{\mathrm{t}}$} & & $0.80 *$ & -0.01 & 0.04 & \\
\hline & & (1.84) & $(-0.06)$ & $(0.38)$ & \\
\hline Adj. $R^{2}$ & 0.49 & 0.44 & 0.52 & 0.49 & 0.46 \\
\hline Obs & 128 & 155 & 155 & 155 & 155 \\
\hline
\end{tabular}




\section{Table 6: Comparison of Corporate Profits and Economic Growth: Japan and the United Kingdom versus United States}

Table 6 compares the relation between corporate profit growth and economic growth in United States and two economies with different tax structures, Japan and the United Kingdom, which shifted from a worldwide taxation system to a territorial system in 2010 (2011) for Japan (the United Kingdom). Panel A provides descriptive evidence. Growth in investment (INV) is measured as the quarterly growth, in percent, in seasonally adjusted gross private domestic investment from quarter $\mathrm{t}-1$ to $\mathrm{t}$. Growth in corporate profits (CP) is measured as the quarterly growth, in percent, in corporate profits, which includes foreign profits earned abroad. Economic growth (GDP) is measure as the quarterly growth (in percent) in seasonally adjusted gross domestic product from quarter t- 1 to t. Tax rate is the average tax rate for the country during the sample period. Tax rate-OECD is the difference between the country tax rate and the average OECD tax rate during the period. Panel B presents the results for regressions of corporate profit growth on quarter-ahead percent growth (in percent) in domestic investment in Japan. Territorial is an indicator equal to 1 during the period when Japan taxed foreign profits under a territorial tax system (2010-2013) and 0 otherwise. All other variable are defined as above. t-statistics with Newey-West correction for autocorrelation are reported in parentheses. $* * *$, and $* * *$ indicate significance at the $0.10,0.05$, and 0.01 levels, respectively.

\section{Panel A: Descriptive Evidence}

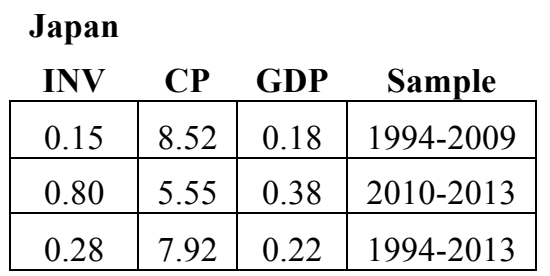

$\begin{array}{ccc}\text { Tax rate } & \text { Tax rate-OECD } & \text { Tax system } \\ 42.99 \% & 11.38 \% & \text { Worldwide } \\ 38.91 \% & 13.40 \% & \text { Territorial } \\ 42.17 \% & 11.79 \% & \end{array}$

\section{United Kingdom}

\begin{tabular}{|c|c|c|c|}
\multicolumn{1}{c}{ INV } & \multicolumn{1}{c}{ CP } & \multicolumn{1}{c}{ GDP } & Sample \\
\hline 0.65 & 0.77 & 1.10 & $1997-2010$ \\
\hline 1.61 & 1.03 & 0.87 & $2011-2013$ \\
\hline 0.85 & 0.85 & 1.07 & $1997-2013$ \\
\hline
\end{tabular}

$\begin{array}{ccc}\text { Tax rate } & \text { Tax rate-OECD } & \text { Tax system } \\ 29.62 \% & -0.36 \% & \text { Worldwide } \\ 24.33 \% & -1.12 \% & \text { Territorial } \\ 28.76 \% & -0.49 \% & \end{array}$

\section{United States}

\begin{tabular}{|c|c|c|c|}
\multicolumn{1}{c}{ INV } & \multicolumn{1}{c}{ CP } & \multicolumn{1}{c}{ GDP } & Sample \\
\hline 1.15 & 2.57 & 1.12 & $1994-2013$ \\
\hline 0.98 & 1.97 & 1.07 & $1997-2013$ \\
\hline
\end{tabular}

$\begin{array}{ccc}\text { Tax rate } & \text { Tax rate-OECD } & \text { Tax system } \\ 39.32 \% & 8.94 \% & \text { Worldwide } \\ 39.27 \% & 10.02 \% & \text { Worldwide }\end{array}$


Table 6. Continued.

Panel B: Territorial Tax System and Domestic Investments

\begin{tabular}{|c|c|c|c|c|}
\hline \multirow[t]{3}{*}{ Dep Var } & \multicolumn{4}{|c|}{$\mathrm{INV}_{\mathrm{t}+1}$} \\
\hline & \multicolumn{2}{|c|}{ Japan } & \multicolumn{2}{|c|}{ UK } \\
\hline & (1) & (2) & (3) & (4) \\
\hline Intercept & $\begin{array}{c}0.13 \\
(0.34)\end{array}$ & $\begin{array}{l}13.11 \\
(1.02)\end{array}$ & $\begin{array}{c}0.52 \\
(1.53)\end{array}$ & $\begin{array}{c}9.88 \\
(1.03)\end{array}$ \\
\hline $\mathrm{CP}_{\mathrm{t}}$ & $\begin{array}{c}0.00 \\
(0.18)\end{array}$ & $\begin{array}{c}0.00 \\
(-0.08)\end{array}$ & $\begin{array}{c}0.02 \\
(0.20)\end{array}$ & $\begin{array}{c}0.03 \\
(0.29)\end{array}$ \\
\hline Territorial $_{\mathrm{t}}$ & $\begin{array}{c}0.60 \\
(1.15)\end{array}$ & $\begin{array}{c}0.73 \\
(0.36)\end{array}$ & $\begin{array}{c}1.38 * * * \\
(2.86)\end{array}$ & $\begin{array}{c}6.15^{* * * *} \\
(5.79)\end{array}$ \\
\hline $\mathrm{CP}_{\mathrm{t}} *$ Territorial $_{t}$ & $\begin{array}{r}0.03 * * \\
(2.38)\end{array}$ & $\begin{array}{l}\text { 0.02* } \\
(1.88)\end{array}$ & $\begin{array}{c}-0.04 \\
(-0.40)\end{array}$ & $\begin{array}{c}-0.28 \\
(-1.53)\end{array}$ \\
\hline $\operatorname{Inv}_{t}$ & & $\begin{array}{l}-0.13 \\
(-0.81)\end{array}$ & & $\begin{array}{c}-0.16 \\
(-0.85)\end{array}$ \\
\hline Term $_{t}$ & & $\begin{array}{c}1.64 \\
(1.10)\end{array}$ & & $\begin{array}{l}-2.47 \\
(-1.03)\end{array}$ \\
\hline T-bill & & $\begin{array}{c}0.56 \\
(1.52)\end{array}$ & & $\begin{array}{l}3.98^{*} \\
(1.69)\end{array}$ \\
\hline Ret $_{t}$ & & $\begin{array}{c}0.07 * * \\
(2.43)\end{array}$ & & $\begin{array}{l}0.07^{*} \\
(1.71)\end{array}$ \\
\hline openness $_{t}$ & & $\begin{array}{c}5.36 \\
(1.58)\end{array}$ & & $\begin{array}{l}-0.58^{* *} \\
(-2.22)\end{array}$ \\
\hline $\mathrm{Tech}_{\mathrm{t}}$ & & $\begin{array}{c}-17.43 * * \\
(-2.64)\end{array}$ & & $\begin{array}{c}-1.07 * * \\
(-2.65)\end{array}$ \\
\hline $\mathrm{FX}_{\mathrm{t}}$ & & $\begin{array}{c}0.04 \\
(0.83)\end{array}$ & & $\begin{array}{c}0.20 \\
(0.02)\end{array}$ \\
\hline Adj. $R^{2}$ & 0.00 & 0.10 & 0.00 & 0.01 \\
\hline Obs & 78 & 78 & 66 & 66 \\
\hline
\end{tabular}




\section{Table 7: Financial Assets in Mobile Industry}

Table 7 examines the change in the financial asset holdings of mobile industries and other industries. Column 1 examines the period during which the difference between the U.S. corporate tax rate and the average OECD corporate tax rate is below the median difference between the two rates $(2.60 \%)$. Column 2 examines the period during which the difference between the U.S. corporate tax rate and the average OECD corporate tax rate is above the median difference between the two rates $(2.60 \%)$. Marketable Securities (Short) is quarterly cash and short-term marketable securities. AT is total assets. Industries are defined by three-digit SIC code for all firms in Compustat. Mobile industries are those with three-digit SIC codes 283, 357, 367, 737, and 738 (De Simone and Stomberg, 2013). tstatistics in the last column measure the difference between financial assets before and after the tax change. t-statistics in the last row measure the difference between mobile and other industries in the same period. $* * *$ indicates significance at the 0.01 level.

\begin{tabular}{lccc}
\hline \multicolumn{4}{c}{ Marketable Securities (Short)/AT } \\
\hline $\begin{array}{c}\text { US Tax - OECD Tax: } \\
\text { Below Median (76 } \\
\text { quarters) }\end{array}$ & $\begin{array}{c}\text { US Tax - OECD Tax: } \\
\text { Above Median (79 } \\
\text { quarters) }\end{array}$ & \\
\hline & $(1)$ & $(2)$ & $14.73^{* * *}$ \\
\hline Mobile industries & 0.13 & 0.23 & $\begin{array}{c}\text { t-statistic (difference between } \\
\text { columns (1) and (2)) }\end{array}$ \\
Other industries & 0.06 & 0.07 & $6.19^{* * *}$ \\
\hline $\begin{array}{l}\text { Difference between } \\
\text { mobile and other } \\
\text { industries }\end{array}$ & & & \\
& $0.08^{* * *}$ & & $0.08^{* * *}$ \\
\hline
\end{tabular}




\section{Table A1: Corporate Profits and Economic Growth}

Table A1 reports the results for regressions of corporate profit growth on quarter-ahead economic growth. In Panel A (B), economic growth is measure as the quarterly growth, in percent, in seasonally adjusted gross national (domestic) product, GNP (GDP), from quarter $t$ to $t+1$. Growth in corporate profits, CPN (CPD), is measured as the quarterly growth, in percent, in national (domestic) corporate profits. Taxdum is an indicator variable equal to 1 during periods in which the difference between the U.S. corporate tax rate and the average OECD corporate tax rate is above the median $(2.60 \%)$. Taxdum*CPN (Taxdum*CPD) is the interaction between Taxdum and national (domestic) corporate profits. Variable definitions are in the Variable Appendix. t-statistics with Newey-West correction for autocorrelation are reported in parentheses. ${ }^{*}, *$, and $* * *$ indicate significance at the $0.10,0.05$, and 0.01 levels, respectively.

Panel A: National corporate profits and quarter-ahead GNP

\begin{tabular}{|c|c|c|c|c|c|}
\hline \multirow[t]{2}{*}{ Dep Var } & \multicolumn{5}{|c|}{$\mathrm{GNP}_{\mathrm{t}+1}$} \\
\hline & (1) & (2) & (3) & (4) & (5) \\
\hline Intercept & $\begin{array}{c}1.48 * * * \\
(8.85)\end{array}$ & $\begin{array}{c}1.84 * * * \\
(8.81)\end{array}$ & $\begin{array}{c}1.84 * * * \\
(8.78)\end{array}$ & $\begin{array}{c}1.34 * * * \\
(4.73)\end{array}$ & $\begin{array}{c}1.42 \\
(1.10)\end{array}$ \\
\hline $\mathrm{CPN}_{\mathrm{t}}$ & $\begin{array}{c}0.03 * * \\
(2.09)\end{array}$ & $\begin{array}{c}0.06^{* * * *} \\
(4.13)\end{array}$ & $\begin{array}{c}0.06^{* * * *} \\
(4.11)\end{array}$ & $\begin{array}{l}0.03 * * \\
(2.34)\end{array}$ & $\begin{array}{c}0.04 * * * \\
(3.01)\end{array}$ \\
\hline TaxDum $_{t}$ & & $\begin{array}{c}-0.72 * * * \\
(-2.73)\end{array}$ & $\begin{array}{c}-0.58 * * \\
(-2.56)\end{array}$ & $\begin{array}{c}-0.43 * * \\
(-2.08)\end{array}$ & $\begin{array}{c}0.25 \\
(1.07)\end{array}$ \\
\hline $\operatorname{TaxDum}_{t} * \mathrm{CPN}_{\mathrm{t}}$ & & $\begin{array}{c}-0.05 * * * \\
(-3.03)\end{array}$ & $\begin{array}{c}-0.06 * * * \\
(-3.58)\end{array}$ & $\begin{array}{c}-0.04 * * \\
(-2.35)\end{array}$ & $\begin{array}{c}-0.04 * * * \\
(-3.13)\end{array}$ \\
\hline Crisis & & & $\begin{array}{c}-1.73 * * * \\
(-9.46)\end{array}$ & $\begin{array}{c}-1.31 * * * \\
(-6.68)\end{array}$ & $\begin{array}{c}-0.71 * * * \\
(-3.54)\end{array}$ \\
\hline $\mathrm{GNP}_{\mathrm{t}}$ & & & & $\begin{array}{c}0.28 * * * \\
(3.13)\end{array}$ & $\begin{array}{c}0.00 \\
(0.03)\end{array}$ \\
\hline Term $_{t}$ & & & & & $\begin{array}{c}-0.48 \\
(-0.39)\end{array}$ \\
\hline $\mathrm{DEF}_{\mathrm{t}}$ & & & & & $\begin{array}{l}15.79 \\
(0.89)\end{array}$ \\
\hline T-bill $t_{t}$ & & & & & $\begin{array}{c}6.26 \\
(1.28)\end{array}$ \\
\hline $\operatorname{Ret}_{t}$ & & & & & $\begin{array}{c}1.00 \\
(1.21)\end{array}$ \\
\hline Recession $_{t}$ & & & & & $\begin{array}{c}-1.04 * * * \\
(-2.84)\end{array}$ \\
\hline openness $_{t}$ & & & & & $\begin{array}{c}0.05 \\
(0.01)\end{array}$ \\
\hline $\operatorname{Tech}_{\mathrm{t}}$ & & & & & $\begin{array}{c}0.07 \\
(1.24)\end{array}$ \\
\hline Productivity $_{t}$ & & & & & $\begin{array}{c}0.01 \\
(0.72)\end{array}$ \\
\hline $\mathrm{FX}_{\mathrm{t}}$ & & & & & $\begin{array}{c}-0.01 \\
(-0.49)\end{array}$ \\
\hline Inv_opp $p_{t}$ & & & & & $\begin{array}{l}0.03^{*} \\
(1.91)\end{array}$ \\
\hline Ineq $_{t}$ & & & & & $\begin{array}{c}-0.15 * * * \\
(-3.42)\end{array}$ \\
\hline Adj. $R^{2}$ & 0.03 & 0.23 & 0.34 & 0.38 & 0.49 \\
\hline Obs & 155 & 155 & 155 & 155 & 155 \\
\hline
\end{tabular}


Table A1. Continued.

Panel B: Domestic corporate profits and quarter-ahead GDP

\begin{tabular}{|c|c|c|c|c|c|}
\hline \multirow[t]{2}{*}{ Dep Var } & \multicolumn{5}{|c|}{$\mathrm{GDP}_{\mathrm{t}+1}$} \\
\hline & (1) & (2) & (3) & (4) & (5) \\
\hline \multirow[t]{2}{*}{ Intercept } & $1.49 * * *$ & $1.87 * * *$ & $1.87 * * *$ & $1.33 * * *$ & 1.52 \\
\hline & $(8.52)$ & $(8.65)$ & $(8.62)$ & $(4.68)$ & (1.17) \\
\hline \multirow[t]{2}{*}{$\mathrm{CPD}_{\mathrm{t}}$} & 0.02 & $0.04 * * *$ & $0.04 * * *$ & $0.02 * *$ & $0.03 * * *$ \\
\hline & (1.64) & $(3.47)$ & $(3.46)$ & $(2.04)$ & $(3.21)$ \\
\hline \multirow[t]{2}{*}{ Taxdum $_{t}$} & & $-0.76 * * *$ & $-0.64 * * *$ & $-0.46 * *$ & 0.21 \\
\hline & & $(-2.83)$ & $(-2.71)$ & $(-2.22)$ & $(0.88)$ \\
\hline \multirow{2}{*}{$\operatorname{TaxDum}_{\mathrm{t}} * \mathrm{CPD}_{\mathrm{t}}$} & & $-0.04 * * *$ & $-0.04 * * *$ & $-0.02 *$ & $-0.03 * * *$ \\
\hline & & $(-2.98)$ & $(-3.14)$ & $(-1.76)$ & $(-3.20)$ \\
\hline \multirow[t]{2}{*}{ Crisis } & & & $-1.62 * * *$ & $-1.19 * * *$ & $-0.58 * * *$ \\
\hline & & & $(-9.03)$ & $(-6.46)$ & $(-3.07)$ \\
\hline \multirow{2}{*}{$\mathrm{GDP}_{\mathrm{t}}$} & & & & $0.30 * * *$ & -0.01 \\
\hline & & & & $(3.36)$ & $(-0.07)$ \\
\hline \multirow[t]{2}{*}{ Term $_{t}$} & & & & & -0.69 \\
\hline & & & & & $(-0.56)$ \\
\hline \multirow[t]{2}{*}{$\mathrm{DEF}_{\mathrm{t}}$} & & & & & 12.71 \\
\hline & & & & & $(0.72)$ \\
\hline \multirow[t]{2}{*}{ T-bill $t_{t}$} & & & & & 7.12 \\
\hline & & & & & $(1.28)$ \\
\hline \multirow[t]{2}{*}{$\operatorname{Ret}_{t}$} & & & & & 0.77 \\
\hline & & & & & (1.07) \\
\hline \multirow[t]{2}{*}{ Recession $_{t}$} & & & & & $-1.07 * * *$ \\
\hline & & & & & $(-2.98)$ \\
\hline \multirow[t]{2}{*}{ openness $_{t}$} & & & & & 0.78 \\
\hline & & & & & $(0.17)$ \\
\hline \multirow[t]{2}{*}{$\operatorname{Tech}_{t}$} & & & & & 0.07 \\
\hline & & & & & $(1.24)$ \\
\hline \multirow[t]{2}{*}{ Productivity $_{t}$} & & & & & 0.01 \\
\hline & & & & & $(0.46)$ \\
\hline \multirow[t]{2}{*}{$\mathrm{FX}_{\mathrm{t}}$} & & & & & -0.01 \\
\hline & & & & & $(-0.38)$ \\
\hline \multirow[t]{2}{*}{ Inv_opp $p_{t}$} & & & & & $0.04 * *$ \\
\hline & & & & & $(2.25)$ \\
\hline \multirow[t]{2}{*}{ Ineq $_{t}$} & & & & & $-0.14 * * *$ \\
\hline & & & & & $(-3.05)$ \\
\hline Adj. $\mathrm{R}^{2}$ & 0.02 & 0.24 & 0.33 & 0.39 & 0.49 \\
\hline Obs & 155 & 155 & 155 & 155 & 155 \\
\hline
\end{tabular}




\section{Table A2: Corporate Profits and Quarter-Ahead Investments}

Table A2 presents the results for regressions of corporate profit growth on quarter-ahead percent growth, in percent, in domestic investment. Growth in investment (INV) is measured as the quarterly growth, in percent, in seasonally adjusted gross private domestic investment from quarter $t$ to $t+1$. Growth in corporate profits (CPD) is measured as the quarterly growth, in percent, in domestic corporate profits from quarter $\mathrm{t}-1$ to $\mathrm{t}$. Taxdum is an indicator variable equal to 1 during periods in which the difference between the U.S. corporate tax rate and the average OECD corporate tax rate is above the median (2.60\%). Taxdum*CPD is the interaction between Taxdum and domestic corporate profits. Variable definitions are in the Variable Appendix. t-statistics with Newey-West correction for autocorrelation are reported in parentheses. ${ }^{*}, *$, and $* * *$ indicate significance at the $0.10,0.05$, and 0.01 levels, respectively.

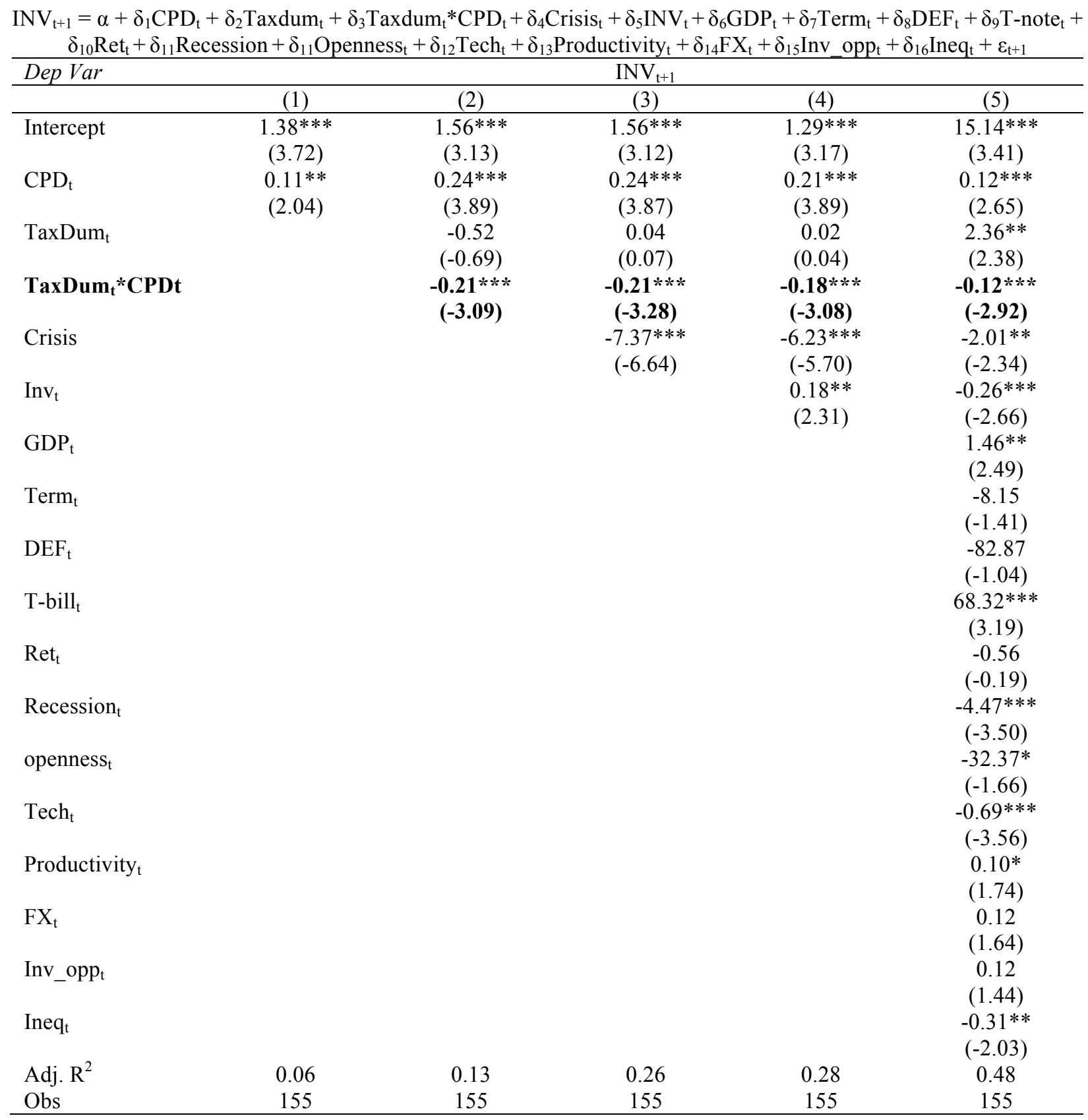




\section{Table A3: Repatriation of Corporate Profits}

Table A3 presents the results of the effect of relative U.S. tax rates on the percentage of quarterly foreign profits earned by U.S. companies that are repatriated. Percentage of foreign profits repatriated (REPAT) is measured in quarter $\mathrm{t}+1$. Growth in corporate profits $(\mathrm{CPN})$ is measured as the quarterly growth, in percent, in national corporate profits from quarter $\mathrm{t}-1$ to $\mathrm{t}$. TaxDum is an indicator variable equal to 1 during periods in which the difference between the U.S. corporate tax rate and the average OECD corporate tax rate is above median $(2.60 \%)$. Variable definitions are in the Variable Appendix. t-statistics with Newey-West correction for autocorrelation are reported in parentheses. $*, * *$, and $* * *$ indicate significance at the $0.10,0.05$, and 0.01 levels, respectively.

\begin{tabular}{|c|c|c|c|c|c|}
\hline \multirow[t]{2}{*}{ Dep Var } & \multicolumn{5}{|c|}{$\%$ Repatriation $_{\mathrm{t}+1}$} \\
\hline & (1) & (2) & (3) & (4) & (5) \\
\hline Intercept & $\begin{array}{c}49.42 * * * \\
(16.57)\end{array}$ & $\begin{array}{c}60.32 * * * \\
(23.90)\end{array}$ & $\begin{array}{c}60.33 * * * \\
(23.81)\end{array}$ & $\begin{array}{c}58.70 * * * \\
(13.94)\end{array}$ & $\begin{array}{c}105.83^{* * *} \\
(3.19)\end{array}$ \\
\hline $\mathrm{CPN}_{\mathrm{t}}$ & $\begin{array}{l}-0.28^{*} \\
(-1.91)\end{array}$ & $\begin{array}{c}-0.23^{* *} \\
(-2.32)\end{array}$ & $\begin{array}{c}-0.24 * * \\
(-2.34)\end{array}$ & $\begin{array}{c}-0.26 * * * \\
(-2.70)\end{array}$ & $\begin{array}{c}-0.08 \\
(-0.69)\end{array}$ \\
\hline $\operatorname{TaxDum}_{t}$ & & $\begin{array}{c}-16.17 * * * \\
(-4.10)\end{array}$ & $\begin{array}{c}-16.09 * * * \\
(-3.90)\end{array}$ & $\begin{array}{c}-15.72 * * * \\
(-3.71)\end{array}$ & $\begin{array}{l}-11.34 * \\
(-1.71)\end{array}$ \\
\hline Crisis & & & $\begin{array}{c}-1.19 \\
(-0.34)\end{array}$ & $\begin{array}{c}0.32 \\
(0.07)\end{array}$ & $\begin{array}{c}0.11 \\
(0.02)\end{array}$ \\
\hline $\mathrm{GNP}_{\mathrm{t}}$ & & & & $\begin{array}{c}1.03 \\
(0.39)\end{array}$ & $\begin{array}{c}-0.82 \\
(-0.34)\end{array}$ \\
\hline Term $_{t}$ & & & & & $\begin{array}{c}110.92 * \\
(1.73)\end{array}$ \\
\hline $\mathrm{DEF}_{\mathrm{t}}$ & & & & & $\begin{array}{l}-344.27 \\
(-0.73)\end{array}$ \\
\hline T-bill $t_{t}$ & & & & & $\begin{array}{l}-340.31 \\
(-1.30)\end{array}$ \\
\hline $\operatorname{Ret}_{t}$ & & & & & $\begin{array}{l}-6.20 \\
(-0.56)\end{array}$ \\
\hline Recession $_{t}$ & & & & & $\begin{array}{c}8.09 \\
(1.00)\end{array}$ \\
\hline Openness $_{t}$ & & & & & $\begin{array}{l}-93.35 \\
(-0.52)\end{array}$ \\
\hline Tech $_{t}$ & & & & & $\begin{array}{l}-0.03 \\
(-0.02)\end{array}$ \\
\hline Productivity $_{t}$ & & & & & $\begin{array}{l}-0.69 \\
(-1.22)\end{array}$ \\
\hline $\mathrm{FX}_{\mathrm{t}}$ & & & & & $\begin{array}{c}0.59 \\
(0.74)\end{array}$ \\
\hline Inv_opp $p_{t}$ & & & & & $\begin{array}{c}0.54 \\
(0.76)\end{array}$ \\
\hline Ineq $_{t}$ & & & & & $\begin{array}{c}2.06 \\
(1.62)\end{array}$ \\
\hline Adj. $R^{2}$ & 0.00 & 0.15 & 0.15 & 0.14 & 0.20 \\
\hline Obs & 128 & 128 & 128 & 128 & 128 \\
\hline
\end{tabular}




\section{Table A4: Aggregate Stock Returns, Dividends, and Subsequent Economic Growth}

Table A4 presents evidence of the relation between the aggregate wealth effect (measured using aggregate quarterly stock returns and aggregate dividends) and one quarter-ahead GDP and personal consumption expenditures. Agg_ret is the aggregate quarterly stock returns. Agg_Div is the aggregate quarterly dividends measured using the definitions in Boudoukh et al. (2007). All other variable definitions are in the Variable Appendix. t-statistics with Newey-West correction for autocorrelation are reported in parentheses. ${ }^{*}, * *$, and $* * *$ indicate significance at the $0.10,0.05$, and 0.01 levels, respectively.

$\mathrm{DV}_{\mathrm{t}+1}=\alpha+\varphi_{1} \operatorname{Agg} \operatorname{Ret}_{t}+\varphi_{2} \mathrm{Agg} \operatorname{Div}_{\mathrm{t}}+\varphi_{3} \mathrm{Term}_{\mathrm{t}}+\varphi_{4} \mathrm{DEF}_{\mathrm{t}}+\varphi_{5}$ One yr $\operatorname{ret}_{t}+\varepsilon_{\mathrm{t}+1}$

\begin{tabular}{|c|c|c|c|c|}
\hline Dep Var & & & & \\
\hline & (1) & (2) & (3) & (4) \\
\hline Intercept & $\begin{array}{c}1.41 * * * \\
(6.38)\end{array}$ & $\begin{array}{c}3.44 * * * \\
(3.27)\end{array}$ & $\begin{array}{c}1.30 * * * \\
(7.15)\end{array}$ & $\begin{array}{c}2.75 * * * \\
(3.26)\end{array}$ \\
\hline$A g g_{-} R_{e t}$ & $\begin{array}{l}2.60 * * \\
(2.26)\end{array}$ & & $\begin{array}{c}3.01 * * * \\
(2.78)\end{array}$ & \\
\hline Agg_Div $v_{t}$ & & $\begin{array}{c}0.79 * * \\
(2.13)\end{array}$ & & $\begin{array}{l}0.55^{*} \\
(1.81)\end{array}$ \\
\hline Term $_{t}$ & $\begin{array}{c}-6.28 * * * \\
(-2.63)\end{array}$ & $\begin{array}{c}-5.53 * * \\
(-2.09)\end{array}$ & $\begin{array}{c}-6.54 * * * \\
(-4.12)\end{array}$ & $\begin{array}{c}-5.76 * * * \\
(-2.97)\end{array}$ \\
\hline$D E F_{t}$ & $\begin{array}{l}-21.35 \\
(-0.84)\end{array}$ & $\begin{array}{l}-37.59 \\
(-1.37)\end{array}$ & $\begin{array}{l}-3.27 \\
(-0.12)\end{array}$ & $\begin{array}{l}-14.09 \\
(-0.48)\end{array}$ \\
\hline One_yr_rt & $\begin{array}{c}21.66^{* * * *} \\
(2.72)\end{array}$ & $\begin{array}{c}21.05^{* *} \\
(2.21)\end{array}$ & $\begin{array}{c}19.55^{* *} \\
(2.35)\end{array}$ & $\begin{array}{l}19.70^{*} \\
(1.98)\end{array}$ \\
\hline Adj. $R^{2}$ & 0.10 & 0.09 & 0.15 & 0.09 \\
\hline Obs & 143 & 143 & 143 & 143 \\
\hline
\end{tabular}

